\title{
PROSAS DE LOPE
}

\author{
José MONTERo Reguera \\ UNIVERSIDAD DE VIGO
}

"A excepción de los vastos estudios sobre La Dorotea, contradictorios algunos, polémicos otros, el Lope narrador está de espaldas al canon". ${ }^{1}$

La ficción en prosa de Lope de Vega constituye un corpus textual no muy extenso - cinco obras $-{ }^{2}$ pero muy interesante por cuanto que en él confluyen no sólo circunstancias y motivos personales ingeniosamente reelaborados, sino también un verdadero propósito de renovación de la prosa áurea en la que este esfuerzo constituye un hito singular. Tal ejercicio literario, desarrollado a lo largo de casi cuarenta años, y sustentado en una

\footnotetext{
${ }^{1}$ Son palabras de Antonio Carreño, ed., Lope de Vega, Novelas a Marcia Leonarda, Madrid, Cátedra, 2001, p. 11. Agradezco a Macarena Cuiñas y Fernando Romo su atenta lectura de este trabajo. ${ }^{2}$ He utilizado como textos de referencia de donde se extraen todas las citas las siguientes ediciones: Lope de Vega, La Arcadia, ed. de E. S. Morby, Madrid, Castalia, 1975; El peregrino en su patria, ed. de J. B. Avalle-Arce, Madrid, Castalia, 1973; Pastores de Belén, ed. de Salvador Fernández Ramírez, Madrid, Renacimiento, s. a. [1930?], 2 vols.; Lope de Vega, Novelas a Marcia
} 
integración hábil de la propia experiencia vital con un amplio conocimiento de las formas narrativas auriseculares, está dirigido, entre otros propósitos, a configurar una imagen del escritor seria y culta, alejada de la de escritor popular, "fácil", que da gusto al vulgo "encerrando los preceptos bajo siete llaves". Este objetivo, que se intensifica en el llamado período De senectute (1627-1635), está ya presente mucho tiempo antes, desde casi sus primeros éxitos en el teatro, y acompañará a Lope, sin conseguirlo, hasta ese testamento literario suyo que es La Dorotea.

En efecto, porque Lope, antes que nada, es el gran dramaturgo del Siglo de Oro, el que, desde fechas muy tempranas (1580-1590) domina la escena española. Cervantes relató con expresivas palabras tal dominio por parte de Lope:

[...] Tuve otras cosas en qué ocuparme; dejé la pluma y las comedias, y entró luego el monstruo de naturaleza, el gran Lope de Vega, y alzóse con la monarquía cómica. Avasalló y puso debajo de su juridición a todos los farsantes; llenó el mundo de comedias proprias, felices y bien razonadas, y tantas que pasan de diez mil pliegos los que tiene escritos, y todas, que es una de las mayores cosas que puede decirse, las ha visto representar o oído decir por los menos que se han representado; y si algunos, que hay muchos, han querido entrar a la parte y gloria de sus trabajos, todos juntos no llegan en lo que han escrito a la mitad de lo que él solo. (Prólogo de Cervantes a sus Ocho comedias y ocho entremeses nuevos, nunca representados, Madrid: Viuda de Alonso Martín, 1615).

El teatro le proporcionó dinero, gloria, mil y una aventuras, lances amorosos, satisfizo - ¿acaso sólo en parte? - su vanidad como hombre de letras; pero también era actividad que Lope llevaba a cabo con un contenido importante pro pane lucrando, esto es, como una actividad que le proporcionaba

Leonarda, ed. de Francisco Rico, Madrid, Alianza Editorial, 1968; La Dorotea, ed. de E. S. Morby, Madrid: Castalia, 1968, 2. ${ }^{\text {a }}$ Ed. revisada. No obstante, he tenido en cuenta estas otras ediciones que en ocasiones se citan puntualmente: Barella, Julia, ed., Lope de Vega, Novelas a Marcia Leonarda, Madrid, Júcar, 1988; Blecua, José Manuel, ed., Lope de Vega, Obras poéticas, Barcelona, Planeta, 1974, 2. ${ }^{\text {a }}$ ed.; -----, ed., Lope de Vega, La Dorotea, Madrid, Cátedra, 1996; Carreño, Antonio, ed., Lope de Vega, Pastores de Belén, Barcelona, PPU, 1991; -----, ed., Novelas a Marcia Leonarda, Madrid, Cátedra, 2001; Entrambasaguas, Joaquín de, Obras completas de Lope de Vega, ed. de [...], Madrid, CSIC, 1965, tomo I, Obras no dramáticas; Fernández Montesinos, José, ed., Lope de Vega, Poesías líricas, Madrid, La Lectura, 1926-1927, 2 vols. ("Clásicos Castellanos”, n. 68 y 75); Fitzgerald, John D., y Leora, A., eds., Lope de Vega, Novelas a Marcia Leonarda, Romanische Forschungen, XXXIV (1915), pp. 278-467; Pedraza Jiménez, Felipe B., Lope de Vega esencial, Madrid, Taurus, 1990; -----, ed., Lope de Vega, Rimas, Ciudad Real, Universidad de Castilla La Mancha, 1993-1994, 2 vols. Profeti, M. G, ed., Novelle per Marzia Leonarda. Traducción de Paola Ambrosi, Venecia, Marsilio editore, 1991. 
buena parte de su sustento - y el de su larga y numerosa familia - ; pero que llevaba aparejada una consideración, por parte de la sociedad de la época, baja, despreciativa, que se muestra en las numerosas críticas de la época sobre el teatro (actores, actrices, mundo que les rodeaba, etc.). Los ejemplos y documentos son muchos y suficientemente conocidos. ${ }^{3}$

Lope era plenamente consciente de tal estado de opinión; en varias ocasiones él mismo se refiere a estas cuestiones y deja traslucir, a veces muy claramente, el desprecio por sus propias obras dramáticas.

En una carta de 1615, Lope califica a las musas que originan sus comedias como "rameras": "Señor, para trasladar los romances no he tenido lugar; mañana me dejarán las Musas, porque en mí no son damas, sino rameras". ${ }^{4}$

Dos años después se refiere a ellas como "ocupaciones viles y ajenas a mi natural condición", en carta bien expresiva: "Yo haré lo que Vex. ${ }^{a}$ me manda y proseguiré este libro que se le dé el fin que Vex. ${ }^{a}$ desea, pues bien estoy cierto que le hubiera tenido si estas viles ocupaciones no se llevarán tras sí la mejor parte de mi vida, que [para] los hombres de algún estudio son las mañanas, de las cuales suelo quedar las tardes tan inútil, que me llego al campo, los más días, sólo a desapasionarse de mí mismo". ${ }^{5}$

En La Circe (1624) merecen el concepto de "versos mercantiles". ${ }^{6}$ En esta misma línea pueden interpretarse unos conocidos y duros versos suyos de la Égloga a Claudio (1632) en los que se refiere a su tiempo malgastado en hacer comedias:

\footnotetext{
${ }^{3}$ Remito sencillamente al trabajo ya clásico de Emilio Cotarelo, Bibliografía de las controversias sobre la licitud del teatro en España [1904], ed. de José Luis Suárez, Granada, Universidad de Granada, 1997.

${ }^{4}$ Carta al duque de Sessa de ijulio de 1615? La reproduce Agustín González de Amezúa, Epistolario de Lope de Vega Carpio, Madrid, Real Academia Española, 1935-1943, 4 vols., vol. III, p. 199. Modernizo ligeramente los textos.

${ }^{5}$ Véase Epistolario, ed. González de Amezúa, vol. III, p. 310. La carta se dirige al Duque de Sesa y está fechada en Madrid, ijunio-julio de 1617 ?

${ }^{6}$ En La Circe (1624), f. 154. Citado por Agustín González de Amezúa, ed., Epistolario de Lope de Vega Carpio, ed. cit., vol. II, p. 167. Este y algunos de los ejemplos mencionados pueden encontrarse en el trabajo de Márquez Villanueva, "Literatura, lengua y moral en La Dorotea", en Lope, vida y valores, Puerto Rico, Editorial de la Universidad de Puerto Rico, 1988, pp. 143-145. Sobre esta actitud de Lope pueden consultarse además del trabajo de Márquez Villanueva, lo que señala González de Amezúa en su edición del Epistolario (vol. I, p. 167), y los artículos de Sturgis E. Leavitt ("Spanish 'comedias' as Pot Boilers", PMLA, 82 [1967], pp. 178-184) y Carroll B. Johnson, que estudia la mezcla de culpabilidad y orgullo de Lope con respecto a su teatro ("El arte viejo de hacer teatro: Lope de Rueda, Lope de Vega y Cervantes", Cuadernos de Filología, 3, 1-2 [1981], pp. 247-259). De una manera general, José María Díez Borque, Teatro y sociedad en la España de Lope de Vega, Barcelona, Antoni Bosch, 1978.
} 
Del vulgo vil solicité la risa, siempre ocupado en fábulas de amores; así grandes pintores manchan la tabla aprisa; que quien el buen jüicio deja aparte paga el estudio como entiende el arte.

Y estos otros, que revelan una postura nada clara - en todo caso no decididamente favorable- hacia sus comedias, de las que parece desentenderse:

Yo, en fin, no las defiendo, Mas, como veo juegos y blasfemias, y de otros vicios viles academias, ni por malas ni buenas las señalo, ni apruebo ni condeno; tendré por bueno lo que fuere bueno, tendré por malo lo que fuere malo. ${ }^{8}$

Y "patética" es - en palabras de Márquez Villanueva - la súplica de 1630 al Duque de Sessa pidiéndole que no deje morir a un sacerdote bajo aquella condena a escribir comedias de lacayos, en carta bien reveladora del estado de ánimo de Lope en sus últimos años:

Días ha que he deseado dejar de escribir para el teatro, así por la edad, que pide cosas más severas, como por el cansancio y aflicción de espíritu en que me ponen. Esto propuse en mi enfermedad, si de aquella tormenta libre llegaba al puerto, mas, como a todos les sucede, en besando la tierra, no me acordé del agua. Ahora, señor excelentísimo, que con desagradar al pueblo dos historias que le di bien escritas y mal escuchadas he conocido o que quieren verdes años o que no quiere el cielo que halle la muerte a un sacerdote escribiendo lacayos de comedia, he propuesto dejarlas de todo punto por no ser como las mujeres hermosas, que a la vejez todos se burlan dellas, y suplicar a V. E: reciba con público nombre en su servicio un criado que ha más de veinticinco años que le tiene secreto, porque sin su favor no podré salir con vitoria deste cuidado, nombrándome algún moderado salario, que con la pensión que

\footnotetext{
${ }^{7}$ Vv. 169-174. Véase la ed. de Miguel García Posada (Lope de Vega, Poesía. Antología, Madrid, EspasaCalpe, 1992), p. 250.

${ }^{8}$ Versos citados por Márquez Villanueva (p. 144) procedentes de El laurel de Apolo (1630). Se encontrarán en la Silva nona, vv. 189-195, ed. de Antonio Carreño, Lope de Vega, Laurel de Apolo, Madrid, Cátedra, 2007, p. 432.
} 
tengo, ayude a pasar esto poco que me puede quedar de vida. El oficio de capellán es muy a propósito. ${ }^{9}$

El teatro era género que no satisfacía uno de sus máximos deseos: sus afanes de gloria, de consideración social y reconocimiento por parte de la República literaria, no tanto como escritor popular, como autor de romances, ni como autor de un sinfín de comedias - algo que nunca iba a conseguir por la propia consideración de la época sobre este género - , sino como escritor docto, como un escritor "culto", utilizando un adjetivo que tanto criticó el propio Lope, pero que en alguna ocasión fue utilizado por algún amigo suyo para definirle:

Del uno y otro a la sublime gloria un peregrino en su fortuna aspira por la voz dulce y cortesano aviso del culto Lope, que en su nueva historia tales sucesos canta con la lira del Peregrino que lo fue en Anfriso. ${ }^{10}$

Lope, pues, anhelaba ser considerado como un "intelectual" de la época. A eso responde toda la serie de largos y cultos poemas, que tantos desvelos le costaron, pertenecientes a los géneros "nobles" del momento: lírica culta, poemas mitológicos, históricos y caballerescos, épica nacional y extranjera. Surgen de inmediato unos cuantos títulos: La Dragontea, La Jerusalén conquistada, La hermosura de Angélica, La Circe, El laurel de Apolo, La Filomena, El Isidro, poema castellano, y un largo etcétera.

$\mathrm{Y}$, también, sus obras narrativas, muy especialmente las de ficción, que responden, fundamentalmente - al menos las tres primeras - a los dos grandes géneros nobles y clásicos de la narrativa del momento: pastoril y bizantina. Sus obras narrativas de ficción responden también a ese propósito capital en Lope ya referido: el de mostrarse como un escritor culto, intención y propósito estos, que aparecen en él muy pronto y que se irán intensificando con el paso del tiempo, en relación sobre todo con tres hechos que marcaron

\footnotetext{
${ }^{9}$ La carta se fecha en Madrid, ijulio-diciembre de 1630? La reproduzco de Nicolás Marín, ed., Lope de Vega, Cartas, Madrid, Castalia, 1985, p. 285. Cfr. el comentario que hace Enrique García Santo-Tomás, Espacio urbano y creación literaria en el Madrid de Felipe IV, Madrid, Iberoamericana, Universidad de Navarra y Vervuert, 2004, p. 134.

${ }^{10}$ Son los tercetos que cierran el soneto de Juan de Arguijo incluido en los preliminares de El peregrino en su patria (ed. Avalle-Arce, p. 49).
} 
decisivamente su vida: la polémica con los preceptistas neoaristotélicos, la polémica gongorina $\mathrm{y}$, también, su deseo de dejar una determinada imagen de sí mismo a la posteridad.

Tales obras constituyen, en este sentido, diversos ensayos de Lope sobre la prosa de ficción de la época, utilizando de manera sucesiva, además, los moldes de mayor fama y éxito en el momento correspondiente: relato pastoril, bizantino, otra vez pastoril (pero a la divino, en pleno ambiente contrarreformista), las novelle. En todos ellos combina además tradición e innovación: Lope también ofrece su particular aportación y dota a esos géneros narrativos de nuevos elementos, de nuevos recursos y modos de contar. Porque, además, por otra parte, la vanidad literaria de Lope le impedía dejar sin tocar cualquier género o tipo de obra en el que demostrar su propio valer; se trataba, en fin, del escritor que quiere mantenerse en candelero, estar en la cabeza de la república literaria de entonces: son intentos diversos del escritor por triunfar en los géneros de moda en la época y así, de igual manera que - al decir cervantino - era el "Monarca" de la producción dramática, serlo en la prosa; en un momento - al inicio, sobre todo, en torno a 1600 - en el que se estaba innovando radicalmente la prosa de ficción en España, lo cual conduciría a la creación de la novela moderna. Es el tiempo de Mateo Alemán (Guzmán de Alfarache, 1598, 1604), de Cervantes (Quijote, 1605-1615; Novelas ejemplares, 1613; Persiles, 1616), de Quevedo (El Buscón, 1605). Lope de Vega, sabedor de la revolución que se estaba llevando a cabo en el campo de la prosa de ficción, también quiere contribuir a esa renovación.

De hecho, todas y cada una de sus obras responden a este parámetro: recoger una tradición ya asentada, clásica, y, partiendo de los modelos anteriores, añadir sus propias modificaciones: recursos, personajes, tipo de acción, etc. En este sentido las prosas de ficción de Lope han de explicarse tendiendo en cuenta todas las motivaciones anteriores y, además, como muestras de la combinación de tradición y modernidad, con un propósito renovador del que Lope era plenamente consciente.

Junto a este aspecto, hay que señalar también que Lope acude por una parte a moldes narrativos que le permitían introducir versos propios: quizás no se sentía completamente cómodo con la prosa y de ahí que introduzca, abundantemente, poesías, género que sí dominaba y en el que se sentía a gusto, ${ }^{11}$ en algunos casos

\footnotetext{
${ }^{11}$ Así lo afirma explícitamente en La Dorotea, IV, 3, p. 350. Véase el texto infra, nota 83.
} 
- Pastores de Belén - lo hace de manera que la prosa casi queda ahogada por los poemas; y de igual forma obras dramáticas: la Arcadia, y el Peregrino en su patria, que incluye cuatro autos sacramentales.

Para llevar a cabo esa mezcla de tradición e innovación que le permita destacar en el campo de la prosa, Lope echa mano de géneros bien conocidos, pero acude también a una de sus mejores fuentes de inspiración: su propia vida. En efecto, la literatura puede mostrarse como espejo de la vida observada, y constituye también, a menudo, testimonio de la vida vivida, e, incluso, de la vida soñada o imaginada. En este sentido, las obras de ficción de Lope de Vega son expresión máxima de sus obsesiones, de sus rasgos existenciales; en definitiva, muestra indudable de la integración de la peripecia vital del autor en su obra hasta el punto de que, sin ella, no se podrían entender por completo. Siguen, además, un proceso intensificador que culmina en $\mathrm{La}$ Dorotea, esa magistral fusión de vida y literatura que constituye sin duda -en palabras de José Manuel Blecua - la "suprema originalidad de Lope". ${ }^{12}$

En estas obras se pueden encontrar, como fuente principal de inspiración, algunos episodios y hechos conocidos de su vida, de los que señalaré seguidamente algunos:

1.- Sus tormentosos amores de juventud con Elena Osorio, que están en el origen de la Arcadia, y que reaparecen en El Peregrino y en Pastores de Belén, hasta llegar a su más bella y perfecta expresión en La Dorotea. De hecho, como ya sugirió en 1950 E.S. Morby, se puede hablar de toda una Materia de Dorotea conformada por la literatura surgida de los amores de Lope con Elena Osorio, de manera similar a como hablamos de una Materia de Bretaña para referirse un amplio grupo de obras literarias..$^{13}$

2.- Su obsesión por la envidia, ya presente en la Arcadia, donde se incluye un retrato del escritor con estas palabras al pie: Quid homilitate Jnvidia? (ed. Morby, p. 53), y que reaparece sistemáticamente en todas sus obras narrativas.

3.- La relación con Góngora (enemistad y admiración unidas) y su ataque despiadado a los gongoristas. Esto sucede sobre todo en La Dorotea. Pero también en las Novelas a Marcia Leonarda y circunstancialmente en Pastores de Belén.

\footnotetext{
${ }^{12}$ Lope de Vega, La Dorotea, ed. de José Manuel Blecua, Madrid, Cátedra, 1996, p. 16.

${ }^{13}$ Véase E.S. Morby, "Persistence and Change in the Formation of La Dorotea", HR, 17 (1950), pp. 108-125 y 195-217; cfr. Márquez Villanueva, ob. cit., p. 147. Más recientes son los trabajos de Enrique García Santo-Tomás, "Creación / recreación: Lope de Vega y las bofetadas a Elena Osorio", Criticón, 65 (1995), pp. 55-63 y Marcella Trambaioli, "Una pre-Dorotea circunstancial de Lope de Vega: Los ramilletes de Madrid. II. Las polémicas literarias y la dimensión política", Criticón, 96 (2006), pp. 139-152.
} 
4.- Sus alardes eruditos: presente en todas sus obras, desde fechas muy tempranas: Lope quiere demostrar, en consonancia con lo ya señalado más arriba, que es tan sabio como el que más y que maneja tanta bibliografía y erudición como el mejor de los humanistas. Todas sus obras narrativas de ficción constituyen un impresionante despliegue de citas y referencias cultas.

5.- Sus alardes de otro tipo: Pastores puede explicarse también como alarde poético. Maneja un número muy amplio y diverso de metros y estrofas, con pies forzados a veces muy difíciles. Acaso esto pueda explicarse también porque no se sentía cómodo en la prosa y acude con frecuencia al verso (Arcadia, Pastores) o al teatro (Peregrino y Arcadia).

6.- La astrología, a la que era tan aficionado, y que aparece, cuando menos, en La Arcadia, Peregrino, Pastores y Dorotea.

7.- Su lucha con los preceptos literarios, esto es, su aspecto como teórico literario, pues, como afirma Antonio Carreño se trata del "gran poeta crítico - con Herrera- de nuestra literatura". ${ }^{14}$ Por ello son frecuentes sus digresiones, cuando no discusiones, sobre los más variados aspectos de la literatura.

Al final de esta trayectoria narrativa ha de situarse La Dorotea, sin duda el más personal de todos estos ensayos en lo que se refiere al género; acaso también su ensayo de obra narrativa nueva, su aportación más particular y personal a la ficción en prosa del Siglo de Oro. Al mismo tiempo, La Dorotea constituye el testamento literario-biográfico de Lope, en el que se hallará no sólo la vida vivida, sino la vida que le hubiera gustado haber vivido y la vida o biografía que se quiere transmitir a la posteridad. Es esa la razón fundamental, creo, por la que en esta obra aparecen todas las obsesiones vitales de Lope, aquellas que ya había ido desperdigando en sus obras anteriores, en mayor o menor medida, según la fecha de composición de esas obras: erudición, astrología, petulancia y presunción, antigongorismo...

La narrativa de ficción de Lope constituye en definitiva un proceso de renovación de la narrativa áurea, autobiografía y transfiguración literaria que culmina en La Dorotea.

\footnotetext{
${ }^{14}$ Antonio Carreño, "La otra Arcadia de Lope de Vega: Pastores de Belén”, Adolfo Sotelo Vázquez y Marta Cristina Carbonell, eds., Homenaje al profesor Antonio Vilanova, Barcelona, Universidad de Barcelona, 1989, vol. I, pp. 137-155. La cita en p. 146.
} 
Prosas de Lope

\section{LOPE DE Vega ANTE LA LITERATURA PASTORIL}

Lope se inicia en el campo de la prosa de ficción con la novela pastoril, a la que dedica dos obras importantes - y no bien conocidas, pese a su alto valor - : La Arcadia (1598) y Los pastores de Belén (1612). Es un momento ya tardío para este género: la novela pastoril había triunfado años antes, sustituyendo en el gusto de la época a los libros de caballerías (Diana, 1559; Diana enamorada, 1564; Galatea, 1585), pero que se extenderá hasta bien entrado el siglo XVII (el último relato pastoril se publica en 1633). Lope, pues, acude a un molde genérico culto, noble, que, además de sus antecedentes clásicos e italianos, se encuentra en el momento, quizá, de mayor éxito y consolidación. Sólo así se explica que en 1599 aparezca una contrafacta a lo divino: Primera parte de la Clara Diana a lo divino repartida en siete libros (Zaragoza: Lorenzo de Robles, 1599).

Lope acude a este género para demostrar que es también un buen escritor de novelas pastoriles, e introduce nuevos elementos y características que crearán escuela. Así, en La Arcadia, Lope asume y emplea las convenciones del género siguiendo los modelos de Sannazaro y Montemayor, pero añade otros elementos que permitirán a Antonio Rey Hazas distinguir tres grandes líneas en la evolución de la novela pastoril: 1) Los que siguen la línea pastoril-(bizantino-cortesana) y neoplatónica de Montemayor, como Gil Polo y Cervantes; 2) los que moralizan y mixtifican diversas tendencias, como Enciso o Lofraso; y 3) los que prefieren acentuar el autobiografismo y rechazar el neoplatonismo al tiempo que el sostén bizantino, e incluyen elementos de miscelánea erudita: Lope de Vega y Cristóbal Suárez de Figueroa. ${ }^{15}$

Efectivamente, porque Lope ha dotado a su primera novela pastoril de un importantísimo contenido erudito, donde se muestra claramente la tendencia manierista ya en el camino del Barroco hacia la complejidad, la ornamentación y el decorado, que llevan a que, en ocasiones, la erudición o las digresiones parezcan tener más importancia que el tema en sí. ${ }^{16}$ Esta tendencia llevará a la pastoril a confluir con las misceláneas del siglo XVI dando lugar a, en palabras de Antonio Rey Hazas, la configuración de la novela como "miscelánea" morfológica, de acuerdo con esquemas que responden

\footnotetext{
${ }^{15}$ Véase el trabajo de Antonio Rey Hazas, “Introducción a la novela del Siglo de Oro, I. (Formas de narrativa idealista)", Edad de Oro, I (1982), pp. 65-105.

${ }^{16}$ Véase ahora el trabajo de José Manuel Trabado Cabado, "Poética y manierismo en La Arcadia de Lope de Vega", Anuario Lope de Vega, 4 (1998), pp. 347-357.
} 
a ejercicios paraescolares, en los que se integra una considerable cantidad de erudición y doctrina, con el fin de enseñar deleitando: "Esta tendencia, que ejemplifica mejor que ninguna otra obra la picaresca Vida de Guzmán de Alfarache (1599-1604) de Mateo Alemán, está ya prefigurada en la novela de Lope, a causa de la magna erudición que inserta y de la lista alfabética que nos ofrece, rasgos ambos fundamentales de las misceláneas, silvas y lecciones varias que abundan entre las publicaciones de los siglos XVI y CVII". ${ }^{17}$

Junto a este contenido erudito, Lope dota a La Arcadia de otro rasgo novedoso y definitorio: es obra que se gesta casi en exclusiva "en la matriz del vivir anecdótico personal del escritor", 18 esto es, con un contenido autobiográfico muy destacado. La obra, en primer lugar, es resultado último de sus amores con Elena Osorio. Estos amores acabaron en un tormentoso proceso judicial por los famosos libelos de nuestro escritor contra Elena y su familia que le condujeron, en 1588, a ocho años de destierro de la Corte. Lope viaja y se establece en Lisboa, primero, Valencia y Toledo, después; hasta que en 1592 entra al servicio del Duque de Alba - también desterrado - y reside en la corte del Duque, en Alba de Tormes, hasta 1596. Sus ocupaciones allí no debieron ser arduas, lo que le permitió dedicarse a hacer literatura. En efecto, su estancia al servicio del Duque supuso la elaboración de, al menos, tres obras teatrales (La pastoral de Jacinto, Los amores de Albanio e Ismenia y La Arcadia), y una extensa obra pastoril, de igual título a la última teatral referida, compuesta, según el criterio más generalizado, entre 1592 y $1596 .{ }^{19}$

\footnotetext{
${ }^{17}$ Antonio Rey Hazas, op. cit., p. 89. Cfr. Alexander McNair, "Reconsidering the Didactism of Lope de Vega's Arcadia", Romance Notes, 42, 1 (2001), pp. 97-105.

${ }^{18}$ Son palabras de Avalle-Arce que la incluye dentro del capítulo V ("Autobiografía y novela", pp. 141-174) de su La novela pastoril española (Madrid, Istmo, 1975, 2. ${ }^{a}$ ed. corregida y aumentada) como perteneciente al grupo de libros pastoriles que se distingue "por su gestación casi exclusiva en la matriz del vivir anecdótico personal del escritor", p. 141. Sobre La Arcadia, pp. 158-166 y 173-174.

${ }^{19}$ Además de los ya clásicos trabajos de Frida Weber de Kurlat (“El Lope-Lope y el Lope-prelope. Formación del subcódigo de la Comedia Nueva", Segismundo, XII, 1976, pp. 111-131) y Juan Oleza ("La propuesta teatral del primer Lope de Vega", Teatro y prácticas escénicas. II: La comedia, Londres, Tamesis Books, 1986, pp. 251-308), sobre la producción literaria lopesca en Alba de Tormes ha de consultarse la monografía de Rafael Osuna (La Arcadia de Lope de Vega: Génesis, estructura y originalidad, Madrid, R. A. E., 1973), especialmente las pp. 81-120; los trabajos de Jesús Cañas Murillo, "Tipología de los personajes en el primer Lope de Vega: las comedias del destierro", Anuario de Estudios Filológicos, XIV (1991), pp. 75-95, y Honor y honra en el primer Lope de Vega: las comedias del destierro, Cáceres: Servicio de Publicaciones de la Universidad de Extremadura, 1995; José Roso Díaz, "El recurso del engaño en la obra dramática del primer Lope de Vega", Hesperia, II (1999), pp. 115126; Antonio Carreño, "Lope y el ciclo de iuventute", Iberoromania, 56 (2002), pp. 4-32, y Dominick
} 
Este libro puede dar una buena idea, por una parte, de cómo se pasaba el tiempo en la corte de Alba de Tormes: juegos diversos, música, representaciones teatrales, tertulias filosóficas sobre diversas materias (amor, poesía), etc., realizados por personajes literarios que, por otra parte, disfrazan a personas reales, de identidad conocida o que se puede conjeturar: Belardo no es otro que el propio Lope de Vega, a través de uno de sus seudónimos predilectos; Anfriso pudiera ser Don Antonio de Toledo, Duque de Alba; Brasildo, probablemente Juan Blas de Castro, músico y amigo de Lope que reaparecerá en Pastores de Belén; Bresinda, la madre del Duque; Lucindo, Don Diego, el hermano bastardo del Duque; Alcino, Jerónimo de Arceo, secretario del hermano bastardo del Duque; y Tirsi, el poeta Diego Hurtado de Mendoza, ayo de Don Antonio de Toledo. ${ }^{20}$

La presencia, pues, de la vida de la corte albana se hace materia tangible y principal de La Arcadia, y muy especialmente en lo que tiene que ver con el propio Lope: sus alardes eruditos, la presencia de la magia, que, al decir de Javier Blasco, lo invade todo en La Arcadia, ${ }^{21}$ episodios concretos como las posibles referencias a sus amores con Elena Osorio, hechos acaecidos en Alba de Tormes...; todo ello se plasma no tanto ya en datos y hechos concretos (a veces muy desfigurados), sino, sobre todo, en el tono general de desengaño que presenta la obra ${ }^{22}$ y que llevará incluso al propio Belardo (=Lope) a usurpar el papel de Anfriso. En efecto, Lope llega a Alba de Tormes tras varios años de destierro y un penoso proceso judicial, que le conducen a un tono pesimista y desengañado que se acentúa, sin duda, en 1593 con el fallecimiento de su hija mayor, Antonia Clara, y en 1594, con la muerte de su mujer Isabel de Urbina.

Cabría hablar en este sentido no tanto de autobiografía cuanto como de proyección de un estado de ánimo, que alcanza a otros personajes utilizados por Lope para expresar su propio sentir, como desfogue de sus propios

\footnotetext{
Finello, "Alba de Tormes y el ambiente dramático en torno a la Arcadia de Lope de Vega", Anuario Lope de Vega, 9 (2003), pp. 211-224. Tangencialmente también puede consultarse Antonio Rey Hazas, "Los comendadores de Córdoba: hacia la fórmula definitiva de la tragicomedia barroca"; Anuario de Estudios Filológicos, XIV (1991), pp. 413-425.

${ }^{20}$ Para todos estos apectos debe acudirse a la monografía de Rafael Osuna, ya citada en la nota anterior.

${ }^{21}$ Véase Javier Blasco, "Entre la magia de amor y la magia de la memoria. Hermetismo y literatura en La Arcadia, de Lope”, Edad de Oro, XI (1990), pp. 19-37, p. 20.

${ }^{22}$ Véanse las certeras páginas que Rafael Osuna ha dedicado a este asunto, op. cit., pp. 65-77. Consúltese también del mismo investigador, "La forma interior de La Arcadia de Lope de Vega", BBMP, XLV (1969), pp. 255-269.
} 
sentimientos; así se justifica desde la portada del libro, con la afirmación siguiente: "De Bernardo es el blasón, las desdichas mías son" (ed. Morby, p. 51). Esta leyenda, por cierto, rodea al blasón con las famosas diecinueve torres del escudo que Lope incluye también al inicio de su Peregrino y que motivaron la acerada crítica de Góngora. Justificación similar se puede encontrar en el prólogo: “[...] Si alguno no advirtiese que a vueltas de los [pensamientos] ajenos he llorado los míos, tal en efeto como fui quise honrarme de escribirlos [...] antes es conforme a la esperanza de una Vega humilde el fruto de pastores que lo parezcan tanto, y más tratando amores con desdichas, que cayeron en mí como en su mismo centro". (Ed. de Morby, p. 56).

En efecto, Lope de Vega, a vuelta de las ajenas, llora sus propias desdichas. Los ecos en este sentido son muy numerosos y sólo señalaré un ejemplo para mostrar cómo la vida del propio Lope lo inunda todo. Muy al inicio, en la primera conversación entre Belisarda y Anfriso, esta le dice "Bien digo yo que has leído esta mañana tus libros, y que quieres venderme tu descuido vestido de unos encarecimientos, como si se pudiese comprar mi cuidado con mentiras" (ed. Morby, p. 77); parece más una reprensión destinada a Lope que no al Duque. La vida de Lope, pues, se convierte en aspecto fundamental a la hora de explicar la génesis de su primer ensayo pastoril.

Casi quince años después, Lope acude al mismo modelo y publica en 1612 Pastores de Belén, uno de los escasos ejemplos de libro de pastores pastoril a lo divino que han llegado hasta nosotros. En efecto, Pastores de Belén ha de insertarse en primer lugar dentro de la rica tradición de literatura a lo divino que en el caso español cuenta con ejemplos muy destacados: Sebastián de Córdoba, San Juan de la Cruz y un largo etcétera; en este sentido, Pastores tiene siempre el referente de La Arcadia, su otro libro pastoril. ${ }^{23}$

\footnotetext{
${ }^{23}$ Véase por ejemplo la dedicatoria a Carlos Félix (ed. Fernández Ramírez, vol. I, p. 17) y el párrafo final de la obra en el que Belardo [= Lope] se dirige a la zampoña (ed. cit., vol. II, p. 182): "Si en otras ocasiones me havéis parecido rústica y bárbara, Zampoña mía, quando al son vuestro cantaba yo los pastores de mi patrio Tajo, sus vanos amores y contiendas a vueltas de los errados pensamientos de mis primeros años: ¿qué me parecéis ahora que me havéis ayudado a cantar los Pastores de Belén, sus honestos pensamientos, dirigidos a las justas alabanzas de aquella hermosa Virgen, que enamora los choros de los ángeles?". Lope había terminado La Arcadia en forma similar (ed. Morby, pp. 451-452). Los preliminares de Pastores insisten en la misma relación a través de los versos de Tamayo de Vargas ("De pastor a pastor va / lo que va de amor a amor/ [...] está, Lope, en vuestra mano, / siendo tan perfecto humano, / ser tan perfecto divino", p. 20.) y de Nectalvo (trasunto posible del propio Lope?): "Lope, por ser peregrino / en cuanto hacéis y decís / vos a vos os traducís / de lo humano a lo divino" (ed. cit., p. 22).
} 
A este aspecto primero y fundamental de la obra se le añaden algunos elementos característicos de los libros de pastores, ya desde el mismo inicio, que no es sino un recuerdo del inicio de la Diana. Si esta había comenzado:

Baxaba de las montañas de León el olvidado Sireno, a quien Amor, la fortuna, el tiempo trataban de manera que el menor mal que en tan triste vida padecía, no se esperaba menos que perdella. (Jorge de Montemayor, La Diana, ed. Asunción Rayo, Madrid: Cátedra, 1991, p. 109).

Pastores lo hace de manera similar:

Bajaba de las montañas de Judea a la torre de Belén, puesta una milla de la sagrada Elia, el pastor Aminadab, descendiente del Tribu [sic] y casa de Jacob [...] (ed. cit., vol I, p. 29).

Pero Lope elimina todos aquellos aspectos que han de quedar fuera de una obra sacra. En efecto, como señaló Avalle-Arce, nuestro escritor, una vez situada la obra en un molde clásico lo va a superar espiritualmente, hasta tal punto que el único parecido con el modelo es la condición pastoril de los personajes. Con todo, "estos pastores no pertenecen a la tradición bucólica sino a la bíblica: son los pastores de la Adoración. Pero ya se ha visto cómo en Fray Luis de León la doble identidad del pastor evoca y mezcla estos dos mundos. Algo semejante ocurre aquí, pues si bien el personaje es el pastor bíblico, su modus vivendi es novelístico, despojado, claro está, de lo que no condice [sic] con la intención divinizadora. En otras palabras, en los Pastores de Belén la materia es sacra, mientras que la forma es profana" ${ }^{24}$

Pastores se compone de cinco libros de extensión más o menos similar, en los que se narran historias bíblicas muy diversas que culminan en el tercer libro con el nacimiento de Cristo y la adoración posterior: "[...] iba el pastor dichoso revolviendo en la memoria aquellas antiguas historias de la creación del mundo, tapizes que por la ancianidad del tiempo intentaban los años cubrir de olvido", (I, p. 29), se señala al comienzo de la obra. Las historias sirven, entre otras cosas, para entretener a los diversos personajes (I, p. 33), que sucesivamente se van encontrando y reuniendo, formando grupos más o menos numerosos. El tercer libro es el núcleo porque en él se relata la llegada a Belén de la Virgen María y San José y el nacimiento del Niño Dios (II, p. 10).

\footnotetext{
${ }^{24}$ Véase La novela pastoril española, op. cit., p. 271.
} 
El relato del nacimiento presenta aspectos costumbristas y de cotidianeidad, a la vez que "rompe sus propios límites, situándose entre lo maravilloso e idílico", ${ }^{25}$ y acaba (libro V, vol. II, p. 182) con los preparativos de la familia sagrada para su huida a Egipto. En realidad este libro gira en torno a un recurso muy sencillo: un narrador hace contar a otros narradores (en un número muy amplio, pues hay más de cincuenta personajes) la historia bíblica en torno al nacimiento de Jesús. En el seno de esas narraciones se incluyen digresiones sobre diversos aspectos (neoplatonismo, poesía, etc.), se refieren juegos de entretenimiento de la época, muy en la línea de lo que se suele hacer en los libros de pastores.

Pero todo ello conducido a otros fines que no son los habituales en las novelas pastoriles y que dotan a la obra de un elemento novedoso importante: se trata de narrar el nacimiento de Cristo. Nos encontramos, efectivamente, ante una pastoril a lo divino, con un fin, parece lógico, fundamentalmente didáctico, que se inserta de lleno en el contexto de la literatura contrarreformista española (el propio Lope con El peregrino en su patria [1604], Cervantes, con Los trabajos de Persiles y Sigismunda [1617]). Es el tiempo en el que autores, géneros y obras muy populares, de gran éxito y plenamente consolidados, son utilizados con propósito de propaganda católica (Sebastián de Córdoba, 1575; Clara Diana a lo divino, 1599). En este sentido, Pastores presenta un contenido didáctico importante - no habitual en la novela pastoril - que se plasma, por un lado, en que es lectura que Lope recomienda a su hijo Carlos Félix para entretener mejor sus niñeces: "Estas prosas y versos al niño Dios se dirigen bien a vuestros tiernos años; porque si él os concede lo que yo os deseo, será bien que, cuando halléis Arcadias de pastores humanos, sepáis que estos divinos escribieron mis desengaños, y aquellos mis ignorancias. Leed estas niñeces, comenzad en este Christus, que él os enseñará mejor cómo havéis de passar las vuestras. Él os guarde". (Ed. cit., vol. I, p. 17). ${ }^{26}$

Por otro lado, Pastores se inscribe en la tradición de los exempla bíblicos, dentro de los ritos y tradiciones religiosas navideñas: "En el contexto de la Contrarreforma [...] los Pastores se definen también no tan sólo como texto novelesco sino también didáctico. Se acomoda al exempla bíblico, [sic] ya

\footnotetext{
${ }^{25}$ Véase Antonio Carreño, art. cit. (1989), pp. 137-8.

${ }^{26}$ Este y otros elementos es lo que ha llevado a plantearse recientemente sobre el contenido de literatura infantil que pueda llevar consigo esta obra. Véase Florence Raynié, "Pastores de Belén, de Lope de Vega: ¿Una novela para niños?”, Didáctica (Lengua y Literatura), 14 (2002), pp. 195-210.
} 
dentro de la representación gráfica y en miniatura de "nacimientos" (San Francisco de Asís fue su iniciador); de los ritos religiosos navideños; de la representación medieval de los mismos misterios, y de la importancia que el dogma de la Virgen-Madre adquirió en la Teología Católica [...] esta figuración plástica de la "Adoración" se acomoda también con la ejemplificación visual que proclamaba San Ignacio en los Ejercicios espirituales, y con los métodos que la nueva devoción inculcaba en devocionarios religiosos. Era la técnica - visual, plástica, emotiva - practicada por la predicación religiosa [...] Los diminutos tomillos en octavo en que circularon los Pastores de Belén, de fácil manejo, satisfacían - de ahí el éxito - esa devoción con frecuencia a flor de piel, lírica, imaginativa, sensual. A su popularidad alude Góngora en 1621 en un soneto ("Aquí del Conde Claros...) donde asigna al famoso "alter ego" de Lope - Burguillos - como autor de los Pastores".27

Las novedades que presenta Pastores, se refieren también, por ejemplo, al tratamiento del nacimiento de Dios, por cuanto que en la tradición anterior (tanto en la literatura como en las artes plásticas), el centro sobre el que giran las obras es el anuncio del ángel; aquí, sin embargo, el centro es la adoración. En este sentido, Pastores de Belén ha podido ser definido como una "formidable pastorela polifónica" ${ }^{28}$ para celebrar a Dios recién nacido y como un variado palimpsesto en el que se funden diversas tradiciones (clásica, bíblica, renacentista) y variedades de formas métricas y personajes.

En este aspecto, la obra presenta un número muy elevado de composiciones poéticas, en número muy superior a cualquiera de las otras obras narrativas de Lope. En efecto, entre las historias narradas se incorporan numerosas composiciones poéticas que convierten el libro en un impresionante muestrario de la poesía en boga, tanto de la procedente de la lírica culta y las formas italianas, como de la lírica tradicional, que se suceden y se combinan en grado sumo. ${ }^{29}$

Estas composiciones poéticas sirven para fines diversos: resumen, síntesis de lo anterior (p. 73, 81, II.80; II.81 [la historia de Caín y Abel en un soneto], II.82 [origen de las letras], II.83 [el diluvio universal], II.84 [las dimensiones del mundo], II.85 [la torre de Babel]); pasar y entretener el tiempo

\footnotetext{
${ }^{27}$ Antonio Carreño, art. cit., pp. 150-151.

${ }^{28}$ Ibidem, p. 155.

${ }^{29}$ Véase ahora el trabajo de Begoña López Bueno, “Beatus ille y Lope (A vueltas con un 'Cuán bienaventurado')", Edad de Oro, XIV (1995), pp. 197-212.
} 
(p. 107, p. 144, II.117), relajación del autor - y del lector - ante tanta narración ("Fileno hizo estos versos que por no cansaros con la continuada narración de mi historia, puesto que es impossible que a nadie canse, os los quiero referir cantando[...]", p. 47), momentos para la efusión lírica y expresión de los propios sentimientos...

Y, a veces, se convierten en verdadero alarde, no ya sólo por el número y variedad de estrofas que emplea, sino por la dificultad de rima que se propone en algunas de las composiciones: así cuando se simulan justas poéticas (II.38, II.39, II.39-40, II.40-41, con mención de las consonantes que han de seguir los sonetos). También el estribillo siguiente, con llamativos juegos aliterativos:

A la mu, niño, a la muerte, ea ro, rostro al morir, que a mí me importa el vivir.

Lope se haya en plena madurez artística y se nos muestra como un perfecto dominador del verso a través de ciento setenta y seis composiciones poéticas distintas, ${ }^{30}$ algunas de las cuales son una auténtica delicia (II.12), donde, además, se puede encontrar el sabor de la lírica tradicional (II.12, II.13, II.15-16, II.27-29):

Campanitas de Belén, tocada al Alva, que sale vertiendo divino aljófar, sobre el sol que della nace, que los ángeles tocan, tocan y tañen.

Y esta otra, excelentísima y muy conocida:

\section{TEBANDRA}

Las pajas del pesebre, niño de Belén, hoy son flores y rosas, mañana serán hiel.

\footnotetext{
${ }^{30}$ He aquí una relación incompleta: sonetos, p. 30, 32, 73, 81; romances: pp. 35-36 ("con letra", en vv. de 7 y 5), 40-42, 42, 103-104, 117-120; romancillos: 109-111, 111-112, II.177 (con pentasílabos); villancicos: 42-43, 54-55; redondillas: pp. 43-44, 44-45, 45-46, 52, 55; Canciones: p. 48-52; sextetos lira: 56-58; décimas: (pero con vv. octosílabos) 67, 76-78, 90-91, 92, 93, 94; tercetos encadenados: 95-102 (égloga); seis octosílabos: 107-108; sextina: II.131.
} 
Lloráis entre las pajas de frío que tenéis, hermoso niño mío, y de calor también.

Dormid, cordero santo; mi vida, no lloréis, que si os escucha el lobo, vendrá por vos, mi bien.

Dormid entre las pajas, que aunque frías las veis, hoy son flores y rosas, mañana serán hiel.

Pastores de Belén se cierra finalmente con un largo párrafo en prosa de Belardo dedicado A la zampoña en la que de nuevo se ponen en relación las dos obras pastoriles de Lope y se relaciona asimismo con el estado anímico y psicológico de Lope, que es lo que, al fin y a la postre, parece haber guiado la composición de este libro: su arrepentimiento y desengaño de las cosas mundanas:

Pero no puedo negaros, que esta vez havéis empleado vuestro talento en sujeto digníssimo: y satisfecho en parte aquellas fábulas vanas, inútiles, copiosas de mentiras y lisonjas, halagadoras de hermosuras, que en tan breve tiempo feas, han sido luz de mis engaños. Ya no os cuelgo en laureles, ya no en aldavas de oro sino en este portal de Belén derribado y eterno, de donde pienso volveros a tomar, si la vida que allí nació aquella noche, para que cante sus alabanzas me la concede. (Ed. cit., vol. II, p. 182).

${ }^{31}$ Cfr. la ed. de Miguel García Posada (Lope de Vega, Poesía. Antología, ed. de ..., Madrid, EspasaCalpe, 1992, pp. 178-179), que lo comenta así: "En este y los siguientes poemillas Lope ve al Niño Jesús acosado, amenazado por los presentimientos de su futuro o por los hielos de diciembre, siempre indefenso. Esta humanización de la figura de Jesús es la clave primera del gran acierto estético que son estos poemas. Jesús, para Lope, es, por encima de todo, un niño. Por eso no duda en introducir los motivos infantiles de modo realmente conmovedor (vv. 11-12). Todo el poema está organizado sobre el llanto del Niño, molesto por las incomodidades del pesebre: muy en la tradición española (así la Representación del nacimiento de Nuestro Señor de Gómez Manrique), esas pajas que hoy le molestan anuncian las espinas de la pasión [...]". Por cierto que el estribillo lopesco procede del cancionero tradicional y volverá a utilizarlo con retoques Góngora: "Las flores del romero, / linda Isabel / hoy son flores azules, / mañana serán miel". Cfr. lo que dicen sobre este cantar tradicional, ya recogido por Correas, Dámaso Alonso y José Manuel Blecua en su Antología de la poesía española. Lírica de tipo tradicional, Madrid, Gredos, 1992, 2. ${ }^{\text {a }}$ ed. corregida, 4. ${ }^{a}$ reimpresión, pp. 264-265. 
En efecto, porque si hay algo que también destaca en esta obra es su fuerte contenido autobiográfico, al que el propio Lope se refiere en carta de noviembre de 1611 al Duque de Sessa:

Y sepa V.E., señor, que estos días he escrito un libro que llamo Pastores de Belén, prosas y versos divinos a la traza de La Arcadia. Dicen mis amigos (lisonja aparte) que es lo más acertado de mis ignorancias, con cuyo ánimo le he presentado al Consejo y le imprimiré con toda brevedad; que ha sido devoción mía y, aunque de materia sagrada, tan copioso de materia humana y divina, que pienso será recibido igualmente. ${ }^{32}$

Este contenido biográfico se plasma no ya sólo en menciones concretas al propio Lope (soneto de Belardo en I, p. 123; el párrafo anterior, etc.), en acaso posibles dardos contra el gongorismo, ${ }^{33}$ y en la presencia de la astrología a la que tan aficionado era nuestro autor, ${ }^{34}$ sino también, como sucede en $\mathrm{La}$ Arcadia, en la plasmación de un estado de ánimo, muy similar al que inunda su primer ensayo pastoril.

En efecto Lope llega a 1611 en un momento vital caracterizado por el desengaño y el arrepentimiento ${ }^{35}$ que se traduce en una serie de obras de carácter fundamentalmente religioso de entre las que destaco las siguientes:

a) Abril de 1610: tres manuscritos autógrafos de las comedias La hermosa Ester, La buena guarda y El caballero del Sacramento.

b) Febrero de 1611: comedia de asunto bíblico Barlaán y Josafat (Los dos soldados de Cristo).

c) Sin fecha fija, pero entre 1610 y 1612: dos comedias, La historia de Tobías y La madre de la mejor (sobre Santa Ana y el nacimiento de la Virgen María).

d) Soliloquios amorosos de un alma a Dios (1612).

e) Rimas sacras (1614). ${ }^{36}$

\footnotetext{
${ }^{32}$ Cito a través de Carreño, art. cit., 1989, p. 145. Cursiva mía.

${ }^{33}$ Me refiero a estos versos: "Yo no escribo mis versos tropológicos, / ni me precio de machinas versátiles, / ni vivo de aphorismos Astrológicos", ed. cit., vol. II, p. 103.

${ }^{34}$ Aparte de referencias aisladas, Lope incluye una composición en verso en la que una gitana le lee la mano al niño Jesús; se trata, pues, de una lectura astrológica de manos en verso (ed. cit., vol. II, p. 181).

${ }^{35}$ Véase a este respecto lo que señalan Antonio Carreño (art. cit., pp. 139-145) y García Posada (ed. cit., pp. 39-46 y 169-174).

${ }^{36}$ Sobre este poemario ha de consultarse ahora el estudio de Yolanda Novo, Las "Rimas sacras" de Lope de Vega. Disposición y sentido, Santiago de Compostela, Universidad de Santiago de Compostela, 1990, y la excelente edición de Antonio Carreño y Antonio Sánchez Jiménez, Madrid - Frankfurt, Iberoamericana, 2006.
} 
Tal sentir invade también la obra que me ocupa ahora. Pastores es reflejo del arrepentimiento del poeta, en correlato evidente con su circunstancia vital, que se dirige a un ¿auténtico? propósito de enmienda:

No más el Babylónico alboroto, prisión injusta de mis verdes años, de mi patria y razón suspenso loto. Traxéronme los blancos desengaños nuevas del fin, y el tiempo fugitivo passadas horas y presentes daños.

Admite mi humildad, pues tu grandeza primero que a la myrra, incienso y oro, llamó a Belén la pastoril pobreza. ${ }^{37}$

Juan Bautista Avalle-Arce se ha referido también al tono vital de arrepentimiento que invade esta obra de Lope:

[...] los Pastores de Belén dan una anhelante nota, propia de la circunstancia vital en que se halla su autor. El arrepentimiento ha invadido su alma y se reniega de los locos devaneos de la juventud, y de aquellas obras en que se canta esa misma carne que se interpone obstinadamente en su camino de regeneración. La Arcadia, apoteosis del amor humano, destaca nítida su contorno y sobre ella descarga el desaliento inducido por la frágil humanidad del poeta. Los Pastores son el resultado del vano esfuerzo de aniquilar la pastoril profana, la Arcadia, y las memorias que su nombre evoca, y de suplantar todo, en el irremontable curso de la historia, por su versión divina. Inútil empresa ipero qué hermosos versos destiló el corazón del pecador arrepentido al acometerla! ${ }^{38}$

Lope de Vega consiguió un verdadero éxito con sus obras pastoriles. De la primera de ellas se conocen, entre 1598 y 1675, veinte ediciones distintas publicadas sobre todo en Madrid, pero también en Barcelona, Valencia, Lérida, Segovia, Málaga y Amberes. Por lo que se refiere a la segunda, se tiene noticia de diez ediciones de existencia cierta entre 1612 y 1675, y de otras cinco más sobre las que hay algunas dudas. La obra tuvo un éxito considerable,

\footnotetext{
${ }^{37}$ Estos versos proceden de la introducción que Lope incluye al inicio de la obra, vv. 70-75 y 127-129.

${ }^{38}$ Juan Bautista Avalle-Arce, La novela pastoril española, p. 272.
} 
desde muy pronto. ${ }^{39}$ Acaso contribuyan varios factores: formato pequeño (octavo en su mayoría) que favorece una mayor difusión; calidad y número de poemas, de autor, además, ya muy conocido en ese género; por ser libro también didáctico en el seno de la literatura de la Contrarreforma (lo que también haría Lope con El peregrino). Parece indudable, pues, que Lope fue un escritor de gran éxito en el terreno de la novela pastoril, que renovó, y cuyas innovaciones fueron del gusto del público y gozaron del aplauso general.

\section{LOPE DE VEGA ANTE LA LITERATURA BIZANTINA}

Entre uno y otro ensayo pastoril, Lope de Vega acude a otro modelo clásico que competía por la primacía en el gusto popular con los libros de pastores: la novela bizantina. Se trata ahora del tipo de ficción narrativa que vino a sustituir el gusto por los libros de caballerías en lo que se refiere a ser un tipo de relato que mantiene los preceptos aristotélicos de verosimilitud, ${ }^{40}$ unidad, decoro y, al mismo tiempo, capaz de producir en los lectores admiración, por lo peregrino y extraño de sus lances y por la variedad de aventuras que introduce. Se acude entonces a los modelos clásicos de la novela griega de aventuras, que llegó y circuló de manera extensa por los ambientes humanistas y cortesanos. Sus modelos son Heliodoro (Historia etiópica de los amores de Teágenes y Clariclea, que se traduce en castellano en 1554 a partir de la versión francesa de Amyot y, más tarde, en 1587 por Fernando de Mena a través de la traducción latina de Warschewich), y Aquiles Tacio (Leucipe y Clitofonte, que se conoció sobre todo a través de la refundición hecha por Ludovico Dolce en sus Amorosi ragionamenti [1546], traducido por Quevedo con posterioridad, aunque esta versión no llegó a publicarse nunca). El siglo XVI da lugar a las primeras expresiones de este género por medio de dos obras que le proporcionan las características fundamentales que seguirá en España este tipo de literatura: Alonso Núñez de Reinoso, Historia de los amores

\footnotetext{
${ }^{39}$ En carta al Duque de Sessa fechada en noviembre de 1611 Lope dice: “Y sepa V. E., señor, que estos días he escrito un libro que llamo Pastores de Belén, prosas y versos divinos a la traza de La Arcadia. Dicen mis amigos (lisonja aparte) que es lo más acertado de mis ignorancias, con cuyo ánimo le he presentado al Consejo y le imprimiré con toda brevedad; que ha sido devoción mía y, aunque de materia sagrada, tan copioso de materia humana y divina, que pienso será recibido igualmente". Cit. por Carreño, art. cit., 1989, p. 145.

${ }^{40}$ Véase ahora el trabajo de Guillermo Serés, "La poética historia de El peregrino en su patria", Anuario Lope de Vega, 7 (2001), pp. 89-104.
} 
de Clareo y Florisea y las tristezas y trabajos de la sin ventura Isea (1552), que readapta en parte la obra de Aquiles Tacio; y Jerónimo de Contreras, Selva de aventuras (1565), acaso el paradigma ejemplar de la novela de aventuras de la Contrarreforma y la que crea las bases del nuevo género narrativo español, desligado ya de los modelos clásicos.

La obra de Lope consta de cinco libros que se articulan en torno a la subordinación de diversos elementos (digresiones, episodios, autos sacramentales, relatos varios, lances de amor, galanteos, celos, seducciones, desafíos) a la fusión de dos tramas paralelas directamente relacionadas que se entrecruzan a lo largo de la obra: la historia principal entre Pánfilo y Nise y la secundaria entre Celio y Finea, dos parejas de hermanos huidos por error, a causa de la oposición paterna a su relación amorosa que, en realidad no existe, ya que el padre de la joven ha concertado la boda de Nise y Pánfilo con el padre de éste, y no con otro pretendiente como creen los enamorados (cfr. ed. cit., p. 258). ${ }^{41}$

El propósito de Lope se expresa con nitidez: "Respondida, pues, esta objeción, nuestra historia, cuyo fin es mover con los trabajos deste hombre" (p. 336). El objetivo, pues, parece claro: se trata de escribir una narración que, inserta en pleno ambiente contrarreformista, responda a los móviles horacianos de enseñar deleitando y, además, mueva a los lectores. ${ }^{42}$ Pero además de este objetivo del autor, se propone asimismo renovar el género, dotarle de nuevos rasgos y elementos, de tal manera que, partiendo de los aspectos generales que se pueden encontrar en los modelos clásicos y españoles, Lope añade otros que permiten considerar El Peregrino como una obra de especial significación en la evolución de la novela bizantina en España. Lope, en definitiva, quiere hacer en el campo de la novela griega lo mismo que venía haciendo desde aproximadamente 1580 con el teatro. Sus grandes aportaciones a ese género pueden centrarse en los siguientes aspectos:

\footnotetext{
${ }^{41}$ Además del libro ya citado de González Rovira, véase a este respecto el trabajo del mismo investigador sobre "Estrategias narrativas en El peregrino en su patria", Alberto Blecua et alii, Lope en 1604, Barcelona, 2004, pp. 137-150.

${ }^{42}$ Véase la nota 473 de Avalle-Arce (ed. de El peregrino en su patria) y p. 338, momento en que el narrador se 'mete' dentro de la historia de los peregrinos y 'mueve' a los lectores. Para González Rovira "a los delectare y docere añade Lope una tercera función, el mouere, claramente relacionada con la persuasión retórica, señalada en varias ocasiones en el seno de la misma novela como virtud del orador y, por extensión, del narrador" (La novela bizantina de la Edad de Oro, Madrid, Gredos, 1996, p. 218).
} 
a) Consolida y acentúa la tendencia innovadora de Jerónimo Contreras. La peregrinación se hace dentro de España, esto es, Lope hispaniza y actualiza el argumento ya que la obra no sólo sucede en España, sino que incluye también numerosos elementos y referencias a la España de 1600, con un propósito verosimilizador evidente. Este proceso de actualización influirá profundamente en novelas posteriores, y le lleva a limitar el espacio geográfico, que, además, es extraordinariamente conocido y familiar para todos. En este sentido, las "aventuras de Pánfilo y Nise carecen del sentido trascendente de la novela de Heliodoro y de Contreras". ${ }^{43}$

b) La obra responde sobre todo a un objetivo didáctico; ${ }^{44}$ y didactismo entendido desde una vertiente fundamentalmente religiosa, en la que converge la práctica totalidad de los elementos de la narración. En efecto, todos los elementos de la narración se orientan hacia el provecho del lector en una línea concreta: la religiosa. En este sentido, mantiene la tendencia religiosa y simbólica que ya es posible encontrar en la Selva de aventuras de Contreras, pero si en esta era "mística beatería platonizante", ahora, en Lope, es "rígido catolicismo postridentino". ${ }^{45}$ De hecho, la peregrinación de los personajes principales, motivada inicialmente por un asunto amoroso deriva de inmediato hacia una peregrinación religiosa, en la que no perderán momento para visitar cuantos monasterios, iglesias y lugares de culto les salen al paso. De hecho, los viajes de los protagonistas se articulan en un triple eje: "peregrinatio amoris en la estructura convergente de las tramas; peregrinatio religiosa desde el punto de vista argumental; y peregrinatio vitae desde la perspectiva del narrador, quien insiste numerosas veces en el carácter simbólico del devenir de los personajes mediante las citas que cierran cada libro, pocas líneas después de

\footnotetext{
${ }^{43}$ González Rovira, op. cit., p. 214. Cfr. Javier Rubiera Fernández, “El teatro dentro de la novela. De la Selva de aventuras a El peregrino en su patria", Castilla. Estudios de Literatura, 27 (2002), pp. 109-122; Guillermo Serés, art. cit., y Francisco Javier Díez de Revenga, “La imaginación de Lope de Vega: los espacios de El peregrino en su patria", Loca ficta: los espacios de la maravilla en la Edad Media y el Siglo de Oro, Pamplona, Universidad de Navarra, 2002, pp. 189-202.

${ }^{44}$ En este sentido la obra responde a la taxativa afirmación aristotélica de "quien sabe, enseña", según González Rovira (op. cit., p. 210). Se intenta educar, sí, a los lectores, pero de manera manipuladora; en esta misma línea, "Lope sostiene siempre con sus incursiones la veracidad de la historia que nos está relatando, ante la cual se siente tan admirado como, presumiblemente, debe estarlo el incrédulo lector [...] buscará la identificación entre protagonista y lector a través de un narrador medial que represente explícitamente el proceso de recepción esperado”. González Rovira, op. cit., p. 219.

${ }^{45}$ Son palabras de Avalle-Arce, op. cit., 1973, p. 28.
} 
los autos sacramentales, indefectiblemente dedicadas a la reflexión sobre la pregrinatio vitae $[. . .]^{\prime \prime} \cdot{ }^{46}$

c) Vuelve a incluir los característicos lances y peripecias que Contreras había olvidado. De hecho, Lope introduce numerosos elementos de marcado carácter cortesano, procedentes de la novela corta italiana, del teatro, incluido el del propio Lope: lances de amor y de honra, galanteos, seducciones, celos, desafíos...; con, además, marcado propósito actualizador y nacionalizador del género. ${ }^{47}$

d) El Peregrino postula una recompensa final a los esfuerzos de los enamorados viajeros no sólo espiritual, sino también física; una satisfacción amorosa total. ${ }^{48}$

e) Inclusión de elementos picarescos: el infra-mundo carcelario, de manicomios y locos. ${ }^{49}$ En este sentido (otro elemento más de radical novedad, por lo que significa de pugna por la creación de la novela moderna), se ha llegado a considerar El peregrino como la respuesta de Lope a la picaresca, porque si la bizantina era una peregrinatio vitae o peregrinatio amoris, con carga - en este caso concreto - del ambiente doctrinal postridentino, la picaresca es una peregrinatio famis: "Y no olvidemos que la verdadera picaresca también está imantada por los conceptos post-tridentinos. Todo esto gravita sobre

\footnotetext{
${ }^{46}$ Son palabras de González Rovira (op. cit., p. 220). De hecho, continúa este investigador, “En cuanto tiene ocasión, Lope de Vega despliega como en sus mejores autos sacramentales toda la ideología religiosa contemporánea, es decir, los dogmas y preceptos de la contrarreforma, con evidente afán divulgador y panegirista. Para ello incluirá numerosas digresiones sobre temas candentes de la época (libre albedrío, milagros, endemoniados, Inquisición, etc.) [siguiendo casi al pie de la letra los dictados del Concilio de Trento]. Pero sobre todo aprovechará la innovación de Contreras de incluir representaciones alegóricas en el desarrollo de la novela mediante el recurso de hacer testigo presencial de los espectáculos dramáticos a sus personajes, quienes pueden aprehender así conceptos teológicos". (Op. cit., pp. 220-221). Sobre estas cuestiones han de verse las consideraciones de AvalleArce (ed. cit., p. 28) y Rey Hazas (art. cit., p. 102-103).

${ }^{47}$ Sobre estas cuestiones, cfr. González Rovira, op. cit., p. 212). Por otro lado, "Los elementos de la cultura cortesana que hemos señalado pretenden, en primera instancia, acercar el modelo clásico a la sensibilidad del lector de la época. Lope está ensayando un proceso de actualización y nacionalización del género con la inclusión de estos rasgos que serán característicos de nuestra narrativa y teatro barrocos para la edificación de del público, nacionalización que, por otro lado, se apoya también en dos sólidos pilares, destacados por Avalle-Arce como innovaciones de Lope: la delimitación del marco espacio-temporal y la intensificación de la religiosidad" (González Rovira, p. 215). Todo esto redunda en la verosimilitud del relato, si bien Lope va buscando no tanto ya la verosimilitud del relato cuanto la autenticidad del mismo.

${ }^{48}$ Véase Rey Hazas, art. cit.

${ }^{49}$ Avalle-Arce, op. cit., 1973, p. 30.
} 
El peregrino en su patria". ${ }^{50}$ Curiosamente: "Lope introduce una paradoja conceptual: un peregrino en su propia patria [lo que] implica un desafío a la novela picaresca, ya que era el pícaro quien había dado vida a la paradoja de un peregrino en su patria, pero así como las peregrinaciones de éste forman el registro del progreso del vicio, el protagonista de Lope registra la peregrinación de la virtud. Vista así, la novela de Lope se nos aparece como una superación espiritual de la picaresca, ya que está animada por la suposición fundamental de que el camino del hombre en la vida es uno de perfectibilidad. Confrontado con los edictos de Trento, y con la solución literaria a que había llegado Mateo Alemán en su Guzmán de Alfarache (1599), Lope formula en su Peregrino una nueva y original respuesta a los mismos problemas" ${ }^{51}$

f) Inclusión de numerosos elementos autobiográficos.

Todo ello convierte a El peregrino en una obra de especial significación en la trayectoria de la novela bizantina española que, además, cabe ser situada como cabeza de una de las dos líneas fundamentales que sigue este género: a) Corriente clásica, representada por Cervantes (y Enríquez de Zúñiga y Suárez de Mendoza), con geografía universal y onomástica exótica (Persiles, Periandro, Sigismunda...); y b) Corriente innovadora, representada por Lope de Vega (y Quintana y Párraga Martel), con geografía hispánica y onomástica idealizante (Nise, Aminta, Pánfilo...).

Como rasgo fundamental de la innovación lopesca ha de entenderse también la inclusión, una vez más, de numerosos elementos biográficos, ya desde la portada, en la que van de la mano la arrogancia y la admisión de desdichas; los preliminares y el prólogo, cargados de alusiones y referencias personales: envidia, erudición, aspiraciones de ser considerado como escritor culto, afición por la astrología, batalla con los preceptos, ataques recibidos, etc. Con todo ello, Lope desvela además, su aspiración de sentar plaza de humanista cristiano. El peregrino en su patria ha de entenderse en este sentido dentro de esas obras que Lope escribe en torno a 1600, insertas en la lucha contra Góngora y sus seguidores y, por otro lado, la gran batalla a la que dieron lugar sus comedias: la librada con los críticos neoaristotélicos por las reglas y preceptos. Lope se empeña, pues, en crear obras cultas, eruditas, que

\footnotetext{
${ }^{50}$ Son palabras de Avalle Arce, ibidem, p. 32.

${ }^{51}$ Ibidem, pp. 32-33; Antonio Carreño (art. cit., 1989, pp. 290-306) y González Rovira (op. cit., 1996, p. 215) opinan en la misma dirección.
} 
le permitan ponerse a la altura y tratar de tú a tú a los que le atacaban: "La publicación de una nueva novela $[E P p]$ imponía ciertas cautelas y medidas defensivas elementales [ante los ataques que había recibido por la publicación de La Arcadia], ya que Lope no ceja ni en su intención de conquistar a los cultos ni en su vanidad literaria". ${ }^{52}$

Junto a esos elementos, aparecen otros muchos de también marcado carácter autobiográfico:

Alusiones a la casa de Alba, a cuyo servicio había estado unos pocos años antes. ${ }^{53}$

De nuevo aparecen sus amores con Elena Osorio relatados por extenso aquí, aunque con otro desenlace (pp. 174-181). En efecto, Lope refiere a través de otro personaje esa relación, sobre la que volverá en varias ocasiones y, muy destacadamente, en La Dorotea: "Os quiero contar una historia sacada de los libros de mi juventud, a los veinte capítulos de mis años, escrita por mis desdichas e impresa en mi memoria [...] aquella breve tiranía, lazo de la verde edad, engaño de la vista, cárcel del alma, escuridad de los sentidos y, finalmente, hermosura que en las mujeres puso el cielo para tanto mal nuestro, de tal manera cegó mis ojos [...] Como este amor no era platónico, no tengo que disputar por qué partes era honesto, útil y deleitable; basta que a mí me pareció el mayor bien lo que era cifra de tanto mal" (p. 174). La amada recibe ahora el nombre de Aurelia: "libre en sus costumbres [...] gallarda [...] de ingenio claro y atrevido", y actriz (p. 175). La relación se iba haciendo cada vez más intensa y "Ya nos parecía la casa estrecha para nuestro amor y buscábamos las soledades de los campos (p. 176) [...]"; Y duró cinco años (p. 176) hasta que "[...] se dejó vencer Aurelia de las obligaciones de un hombre [trasunto posible de José Francisco Perrenot de Granvela], no de mis méritos" (p. 177). La narración de este suceso real en la vida de Lope acaba con una solución distinta a la verdadera. Aquí Lope decidió tomar hábito, pero de nuevo recomenzó su amor ("Comenzó de nuevo nuestro amor con escándalo general de cuantos nos conocían", p. 180) y acaban pasando los dos a Italia donde "hicimos voto de religión" (p. 180). Estamos, pues, ante un nuevo caso de interrelación de vida y literatura y de transfiguración literaria. A todo esto, el personaje que ha hablado se llama Tirso (= Lope, = Don Fernando en La Dorotea), y se refiere

\footnotetext{
${ }^{52}$ Avalle-Arce, op. cit., 1973, pp. 10-11 y 17.

${ }^{53}$ Véanse las referencias en pp. 172 y p. 457 (con alusión, además, a La Arcadia).
} 
a Aurelia (= Elena Osorio, = Dorotea), e intervienen Feliciano (= Perrenot de Granvela, = Don Bela) y Menandra (¿acaso Marfisa?). Por otra parte, el romance que relata la historia de Fabio (pp. 454-462) parece presentar concomitancias con la historia de los amores lopescos en La Dorotea: es romance confuso donde hay cosas sin aclarar, pero que parecen referirse a algo ocurrido en los años del destierro, cuando Lope podría tener unos veinte años:

[...] Desde el Aries a los Peces

había el sol por su esfera

hecho apenas veinte cursos,

cuando empezaron mis penas.

[...]

Cuanto escribí fue después

Proceso de mi sentencia

$[\ldots]$

Puso mi vida en peligro,

Púsome mal con quien era

Dueño de ella por entonces,

Que estaba mi vida en ella.

Mis secretos publicaba

Con encubierta cautela $[\ldots]^{54}$

En la novela también se hacen referencias precisas a las Fiestas en Valencia (1599) con motivo de la celebración de las bodas de Felipe III con Margarita de Austria. Lope fue testigo presencial de esas bodas; es más participó en una mascarada de carnaval para celebrarlas en la que apareció vestido de Bottarga. ${ }^{55}$ Lope hizo además relación de estas fiestas en su Fiestas de Denia (Valencia, 1599) y en su Romance a las venturosas bodas que se celebraron en la insigne ciudad de Valencia (de la misma fecha). ${ }^{56}$

\footnotetext{
${ }^{54}$ Las citas proceden de las pp. 455-457.

${ }^{55}$ Según señala Felipe Gauna en la Relación de las fiestas celebradas en Valencia con motivo del casamiento de Felipe III, "Consequitivamente después de su horden yuan delanteras deos máscaras ridículas quel uno dellas fue conoscido ser el poheta Lope de Vega el cual venía vestido de Botarga, hábito italiano que hera todo de colorado, con calzas y ropilla seguidos y ropa larga de leuantar de chamelote negro, con una gorra de terciopelo llano en la cabeza, y este yua a cauallo, con huna mula ensillada a la gineta y petral de cascaueles, y por el uestido que traya y arsones de la silla levava colgando diferentes animales de carne para comer, representando el tienpo del carnal [...]". Cit. por Agustín Redondo, "El personaje de don Quijote: tradiciones folklórico-literarias, contexto histórico y elaboración cervantina" , NRFH, 29 (1980), 36-50, pp. 40-41, reimpreso en Otra manera de leer el "Quijote”, Madrid, Castalia, 1998.

${ }^{56}$ Véanse p. 193 y las notas correspondientes de Avalle-Arce n. ${ }^{\circ}$ 259, 272 y 286.
} 
Asimismo, se incluye (pp. 262-270) una epístola de importante contenido autobiográfico, en la que Lope se desdobla nuevamente en otro personaje (Jacinto). La Luscinda de la epístola puede ser trasunto de Micaela de Luján (p. 264) como los "dulces pajarillos" pueden serlo de los hijos habidos de la relación entre Lope de Vega y Micaela Luján. Por otra parte, el final de la composición, muy autobiográfica, según lo ya visto, creo que muestra a ese Lope perseguidor de la fama literaria y de un puesto de primera fila en el Parnaso español de la época:

Donde si espero de mis versos fama, a ti lo debo, que tú sola puedes dar a mi frente de laurel la rama, donde muriendo vencedora quedes.

Además, Pánfilo afirma que "hombre que tan tiernamente escribía furiosamente amaba", con referencia indiscutible al propio Lope; Al decir de Avalle-Arce El peregrino en su patria cae de lleno "en los años climatéricos" de la relación de Lope con Micaela de Luján, "que dejó profundas huellas en la novela, según se verá, entre ellas el nombre homenaje del protagonista, Pánfilo de Luján, y la muy hermosa epístola poética 'Serrana hermosa'“. ${ }^{57}$

No faltan tampoco la presunción y alarde de Lope, que introduce una composición (pp. 391-393) con versos en italiano y versiones de esos mismos versos en valenciano, portugués, vizcaíno, francés, alemán, latín, flamenco etc.; ni la presencia de Belardo, el gran seudónimo literario de Lope, que aparece al menos en dos ocasiones (p. 405 y p. 485), con referencia directa, al menos en el segundo caso, a su autor.

Avalle-Arce señala cómo en una ocasión se otorga al honor un tratamiento un tanto distinto al habitual y afirma que en ello podría encontrarse un elemento más que interrelacione nuevamente vida y literatura. ${ }^{58} \mathrm{Y}$, finalmente, no hay que olvidar las casi continuas dilogías en torno al adjetivo peregrino. En efecto, como han puesto de manifiesto Lara Garrido y González Rovira, tales dilogías "reflejan el propósito del autor de autoproclamarse como ingenio único ante la incomprensión y los ataques recibidos en una época marcada por su destierro"; de hecho, por otra parte, en la representación de esilio que se encuentra en la iconografía de la época (en Ripa, por ejemplo) “aparecen

\footnotetext{
${ }^{57}$ Avalle Arce, op. cit., 1973, p. 13.

${ }^{58}$ Avalle Arce, op. cit., 1973, p. 35; cfr. González Rovira, op. cit., 1996, pp. 212-213.
} 
unidos destierro y peregrinación bajo la misma imagen. El peregrino en su patria es, por tanto, el exiliado en su propio país". ${ }^{59}$

Tal conjunto de novedades, innovaciones y autobiografismo convierten a El peregrino en una obra de especial importancia en el contexto de la novela bizantina española, que, además, gozó de un éxito inicial impresionante: en 1604 se publica en cuatro ocasiones, al año siguiente dos veces más. Se vuelve a editar en 1608 (ya en Bruselas) y en 1618, para luego prácticamente desaparecer durante más de un siglo. Es posible además que existieran otras ediciones de época que no han llegado hasta nosotros. ${ }^{60}$

\section{LOPE DE VEgA ANTE LA NOVELA CORTA DE ORIGEN ITALIANO}

Pasa el tiempo, los gustos cambian, evoluciona la narrativa áurea y un nuevo género empieza a gozar del aplauso general: la novela corta de origen italiano, generalmente, enmarcada. Este tipo de relato ya viene siendo utilizado desde El Patrañuelo de Timoneda (1560), pero es en el siglo XVII cuando alcanza plena actividad. En 1613, por ejemplo, Cervantes se vanagloriará de haber sido el primero en haber "novelado" en España, y los relatos enmarcados inundarán los fondos de las librerías de la época: Antonio de Eslava, Tirso de Molina, Alonso de Castillo Solórzano, Alonso Gerónimo de Salas Barbadillo, Luis Vélez de Guevara... Y, cómo no, también Lope. No podía dejar de tentar también este género, para mostrar su pericia en el tipo de narración que estaba de moda en torno a 1620-1630, pese a los recelos, más bien oposición frontal, que muestra veinte años antes. ${ }^{61}$

Lope compone cuatro novelas cortas a instancias de su amante Marta de Nevares, como bien señala al inicio de la primera de ellas: “No he dejado

\footnotetext{
${ }^{59}$ Véase José Lara Garrido, “El peregrino en su patria de Lope de Vega desde la poética del romance griego", Analecta Malacitana, VII (1984), pp. 19-52, y “La estructura del romance griego en El peregrino en su patria", Edad de Oro, III (1984), pp. 123-142, reimpresos y revisados en Del Siglo de Oro (métodos y relecciones), Madrid, Universidad Europea - CEES ediciones, 1997, pp. 401-470, y González Rovira, op. cit., 1996, pp. 220-221.

${ }^{60}$ En efecto, según señala González Rovira (op. cit., 1996, p. 209), parece que pudo haber más ediciones; cfr. O. M. Villarejo, "Lope de Vega's Peregrino Lists: An Historical Sketch Relative to the Data Produced on This Subject By a Series of Investigators", Hispania, 62 (1978), pp. 1-48. La obra tuvo de todos modos un éxito inicial considerable, con siete ediciones en tan sólo cuatro años para luego caer en el olvido.

${ }^{61}$ Véase a este respecto mi trabajo, "El nacimiento de la novela corta en España (La perspectiva de los editores)", Lectura y signo, I (2006), pp. 165-175.
} 
de obedecer a vuestra merced por ingratitud, sino por temor de no acertarla a servirla: porque mandarme que escriba una novela ha sido novedad para mí [...] Yo, que nunca pensé que el novelar entrara en mi pensamiento, me veo embarazado entre su gusto de vuestra merced y mi obediencia". ${ }^{62}$

No se trata, pues, de un conjunto de relatos enmarcados según el uso de la época: su unidad viene dada por el hecho de ir dirigidas a un mismo destinatario. Compuestas además en fechas diversas, ciertamente Lope nunca se preocupó de reunirlas bajo un mismo título e, incluso, la primera de ellas ni siquiera aparece anunciada en la portada de La Filomena. El reunirlas, pues, bajo el título general de Novelas a Marcia Leonarda es producto de la erudición posterior, con título, por cierto, que ha tenido fortuna. El propio Lope dice al final de la cuarta de ellas que tiene preparada otra más (El pastor de Galatea), ${ }^{63}$ así como, en el prólogo a La Circe, afirma haber compuesto "otras muchas escritas a Marcia Leonarda" ${ }^{64}$ Sea como fuere, hasta nosotros han llegado sólo cuatro: Las fortunas de Diana, La desdicha por la honra, La prudente venganza y Guzmán el bravo. La destinataria única es quien proporciona unidad a las novelas cortas de Lope, a diferencia de lo usual en todos los relatos similares de la época.

Henos aquí, pues, ante un grupo de relatos resultado, en primera instancia, de la petición efectuada a Lope por parte de uno de sus grandes amores: Marta de Nevares. Las novelas, en este sentido, presentan un poso autobiográfico evidente que sin duda contribuye a explicarlas: han de entenderse, primera y primordialmente, como el regalo de un escritor a su amante, esto es como un juego de puro galanteo. Lope quiere festejar a su amada y escribe estas novelas como regalo, de igual forma que le podía haber regalado flores, telas o ricos paños. ${ }^{65}$

\footnotetext{
${ }^{62}$ Ed. Rico, p. 27.

${ }^{63}$ Ed. Rico, p. 178.

${ }^{64}$ Ed. Rico, p. 185.

${ }^{65}$ Desde esta perspectiva, las Novelas a Marcia Leonarda han dado lugar a una jugosa bibliografía, con planteamientos y resultados muy dispares; véanse los trabajos de Asunción Rallo Gruss, "Invención y diseño del receptor femenino en las Novelas a Marcia Leonarda", Dicenda, 8 (1989), pp. 161-180; Juan Diego Vila, "Lectura e imaginario de la 'feminidad' en las Novelas a Marcia Leonarda de Lope de Vega", Silva. Studia Philologica in Honorem Isaías Lerner, Madrid, Castalia, 2001, pp. 697-708, Christina H. Lee, "The Rethoric of Courtship in Lope de Vega's Novelas a Marcia Leonarda", Bulletin of Spanish Studies, 80, 1 (2003), pp. 13-32; Rafael Sánchez Martínez, "El requiebro en las Novelas a Marcia Leonarda", Memoria de la palabra, Actas del VI Congreso de la Asociación Internacional Siglo de Oro, Madrid, Iberoamericana, 2004, vol. II, pp. 1609-1618; y Rafael Bonilla Cerezo, "Mascaras de seducción en las Novelas a Marcia Leonarda", Edad de Oro, XXVI (2007), pp. 91-146.
} 
Por ello, el autobiografismo se hace patenteen las continuas intromisiones de Lope en la obra para dirigirse directamente a la "Señora Marcia", y en diversas referencias habituales en las obras lopescas: digresiones teóricas (p. 46, p. 60-61), alusiones a amigos (Juan Blas de Castro, p. 115), a su casa madrileña (p. 119), a obras propias (El asalto de Mastrique, p. 75), referencias al doloroso asunto Osorio (p. 139: “¡Oh papeles, cuánto mal habéis hecho!”), a las bodas de Felipe III en 1599, a las que asistió y describió (p. 153), ataques al gongorismo (p. 77), pero admiración sin paliativos a Góngora (p. 178), etc.

Y junto a ese poso autobiográfico evidente, que las explica, las novelas presentan también las otras facetas que se han venido señalando en la ficción narrativa de Lope: la erudición, conseguida a través de referencias mitológicas, reflexiones teóricas sobre algunos acaecidos de la narración, y citas abundantes; ${ }^{66}$ y su propósito renovador. En efecto, no se puede analizar las novelas lopescas siguiendo los mismos criterios que las obras de Cervantes, Tirso, Eslava, etc.: mientras que estos escriben relatos enmarcados (el caso cervantino requeriría explicación especial), Lope escribe novelas sin marco - al menos un marco del tipo del que encontramos en las obras referidas - ; pero, por otra parte, no deja de ser consciente de estar escribiendo en el seno de una determinada tradición que él mismo se encarga de repasar, ${ }^{67}$ reconociendo, además, el puesto destacado que ocupa Cervantes:

En tiempo menos discreto que el de agora, aunque de más hombres sabios, llamaban a las novelas cuentos. Estos se sabían de memoria, y nunca, que yo me acuerde, los vi escritos, porque se reducían sus fábulas a una manera de libros que parecían historias y se llamaban en lenguaje puro castellano caballerías [...] y aunque en España también se intenta, por no dejar de intentarlo todo, también hay libros de novelas, de ellas traducidas de italianos y de ellas propias, en que no le faltó gracia y estilo a Miguel de Cervantes. Confieso que son libros de grande entretenimiento y que podrían ser ejemplares, como algunas de las Historias trágicas del Bandelo (ed. Rico, pp. 27-28).

\footnotetext{
${ }^{66}$ Véase Lía Schwartz, "La retórica de la cita en las Novelas a Marcia Leonarda de Lope de Vega", Edad de Oro, XIX (2000), pp. 265-285.

${ }^{67}$ Cfr. Francisco Induráin, "Lope de Vega como novelador”, Relección de clásicos, Madrid, Prensa Española, 1969, pp. 113-167, esp. pp. 139-141; Joaquín de Entrambasaguas, “Las obras en prosa de Lope de Vega", Lope de Vega y su tiempo, Barcelona, Teide, 1961, pp. 222-247; y Carmen R. Rabell, Lope de Vega. El arte nuevo de hacer 'novellas', Londres, Tamesis Books Ltd., 1992, p. 81.
} 
El propósito de competencia con Cervantes - muerto hacía ya tiempo - ${ }^{68}$ parece evidente pues "si también hay libros de novelas, de ellas traducidas de italianos y de ellas propias, en que no le faltó gracia y estilo a Miguel de Cervantes", la de Lope "no la ha oído ni es traducida de otra lengua" (ed. Rico, p. 28). Se trataba pues de emular - y superar, si fuera posible - al que ya por esas fechas se reconocía como el gran novelliere hispano, el Boccaccio Español, en palabras de Tirso de Molina. ${ }^{69}$ Lope adopta en este sentido una actitud muy curiosa, por cuanto que, como ha recordado Juan Bautista Avalle-Arce, "por un lado hurta el bulto a la comparación directa con las Novelas ejemplares de Cervantes, por la forma de presentar las suyas al público; por otro lado, hay una firme actitud de superioridad que invita a la comparación".$^{70}$ Cervantes es modelo, pero también la competencia a quien superar; Lope desarrolla en sus novelas una serie de elementos que colocan sus narraciones en las antípodas de las cervantinas, como ha indicado certeramente Augustin Redondo: "Lope inventa una fórmula original de novela que le permite diferenciarse de su gran rival. El juego y la burla, valiéndose de una espectacular relación humorística entre el narrador y la narrataria, Marcia Leonarda, le conducen a invertir los preceptos y las autoridades. La libertad - muy teatral - de la creación es lo que le interesa y desemboca en el relato en una divertida parodia que se sirve en particular del tema turco, como lo demuestra el caso de La desdicha por la honra".$^{71}$

\footnotetext{
${ }^{68}$ Las novelas aparecen en 1621 y 1624, pero es posible que pudieran haberse compuesto años antes. En todo caso son posteriores a las Ejemplares de Cervantes (1613). Véase mi trabajo "Una amistad truncada: sobre Lope de Vega y Cervantes. (Esbozo de una compleja relación)", Anales del Instituto de Estudios Madrileños, XXXIX (1999), pp. 313-336.

${ }^{69}$ Recuérdense simplemente las referencias a Cervantes de Tirso en Los cigarrales de Toledo de 1624 ("Paréceme, señores, que después que murió nuestro español Bocacio, quiero decir Miguel de Cervantes, ejecutor acérrimo de la expulsión de andantes aventuras", ed. Luis Vázquez, Madrid, Castalia, 1996, p. 236) y de Quevedo en La Perinola de 1632 (pueden verse los elogios quevedescos en la ed. de Pablo Jauralde Pou, Obras festivas, Madrid, Castalia, 1987, pp. 193 y 201).

${ }^{70}$ Juan Bautista Avalle-Arce, "Lope entre dos mundos", p. 343.

${ }^{71}$ Augustin Redondo, "La desdicha por la honra: de la concepción lúdica de la novela a la transgresión ideológica", M. G. Profeti, ed., "Otro Lope no ha de haber". Atti del convegno Internationale, Firenze, Editrice Alinea, 2000, vol. I, pp. 159-173 (La cita en pp. 172-173). El mismo investigador ha dedicado otros dos trabajos complementarios que iluminan la narrativa corta de Lope: "Du contexte historique au jeu narratif dans une nouvelle de Lope de Vega: Guzmán el Bravo (1624), Les Langues Néo-Latines, 310 (1999), pp. 43-67, y “Jugando con los referentes históricos y narrativos: La novela de Lope de Vega, Las fortunas de Diana", Con gracia y agudeza. Studi offerti a Giuseppina Ledda. A cura di Antonina Paba, Cagliari, Università degli Studi di Cagliari, 2007, pp. 121-133. Más lejanos, pero todavía valiosos son los trabajos de Marcel Bataillon, "La desdicha por la honra: génesis y sentido de una novela de Lope", NRFH, I (1947), pp. 13-42; y en Varia lección de clásicos españoles, Madrid, Gredos, 1964, pp. 373-418; y Georges Cirot, "Valeur Littéraire des nouvelles de Lope de Vega”, BHi, XXVIII (1926), pp. 318-356.
} 
Desde luego, parece que Lope pretende algo más que sólo galantear a una amante: él mismo afirma tener varias escritas y, ciertamente, sólo espera el éxito de las primeras para sacar a la luz el resto, como señala en el prólogo de La Filomena:

Hallándome obligado a la protección que ha hecho a mis escritos el divino ingenio de la ilustrísima señora doña Leonor de Pimentel, busqué por los papeles de los pasados años algunas flores - si este título merecen mis ignorancias, pues sólo por la elección se la atribuyo-. Hallé Las fortunas de Diana - que lo primero hallé fortunas ['tormentas'] - , y con algunas epístolas familiares y otras diversas rimas escribí en su nombre ['dedicadas a ella'] las fábulas de Filomena y Andrómeda, y formado de varias partes de un cuerpo, quise que le sirviese de alma mi buen deseo. Pienso que no se perderá por la variedad, de que tanto se alaba la naturaleza, y Tulio, al divino Platón. Si tuviere este suceso, seguiranle algunas obras - que quedan en mis papeles - del mismo género, y cesará la reprehensión de mis amigos, que me persuaden a comunicarlas, venciendo el temor de mi humilde condición por la variedad de los juicios de los hombres. ${ }^{72}$

Lope se servirá de los elementos principales que caracterizan a este género: a) Variedad en la elección de temas (tragedias de honor, historias de cautivos) y geografía (Toledo, Italia, Valencia, mar Mediterráneo, Constantinopla, Sevilla, etc.) diversos; b) Inclusión de versos: son muchos, pero imbricados perfectamente en la narración, a la que sirven de relajación, síntesis, descanso, etc.; c) Abundantes elementos teatrales: no sólo por lo que afirma el propio escritor ("Demás que yo he pensado que tienen las novelas los mismos preceptos que las comedias, cuyo fin es haber dado su autor contento y gusto al pueblo, aunque se ahorque el arte; y esto, aunque va dicho al descuido, fue opinión de Aristóteles", ed. Rico, p. 74), sino porque, incluso, se ha llegado a afirmar que "Los asuntos, tocados fuertemente por el aliento dramático, hasta el punto de que en algunas de ellas quedan patentes las tres partes correspondientes a los tres actos: exposición, nudo y desenlace" ${ }^{73} \mathrm{Y}$ también por el empleo de recursos muy teatrales, por ejemplo la manera de comportarse el galán y la dama, que lo hacen en forma muy similar a como en

\footnotetext{
${ }^{72}$ Ed. Rico, p. 179, cursiva mía.

${ }^{73}$ Son palabras de Federico Carlos Sáinz de Robles, Obras escogidas de Lope de Vega. II: poesía y prosa, Madrid, Aguilar, 1987, 4. ${ }^{\text {a }}$ ed., 2. ${ }^{\text {a }}$ reimp., p. 1523 b.
} 
las comedias; ${ }^{74}$ y d) La erudición, tan querida para Lope, aunque no llega a los excesos de La Arcadia o El peregrino. ${ }^{75}$

Junto a estos elementos, incluye otros que me parecen más novedosos y en los que se puede ver al Lope renovador de este género narrativo. Me centraré en el que creo más importante: las intromisiones constantes del narrador, que conllevan la inclusión de numerosas digresiones, pero de una manera distinta a como se solía hacer en las novelas cortas de la época, y, al mismo tiempo, suponen una manipulación constante y consciente del lector, a quien Lope lleva de la mano: "[...] continuamente se detiene para invitar a la dama a seguir la narración, o pide excusas ante lo impertinente de una digresión. Conjetura sus reacciones; le explica un detalle o simplemente le llama la atención con el cariñoso vocativo de "Señora Marcia". En ello reside (creemos) uno de los máximos atractivos de estos relatos, hablados, más que escritos, dialogados, más que narrados".$^{76}$ Se trata acaso de una de las más importantes simbiosis de autobiografía y renovación genérica de las llevadas a cabo por Lope. Y en esto, además, se ha creído ver uno de los rasgos definitorios de la novela moderna. En efecto, como señala Carmen Rabell,

[en las Novelas a Marcia Leonarda] se muestra un narrador ambivalente que lo mismo rompe con las leyes morales que con las poéticas y retóricas y le pide disculpas a su narratario como si fuera vigilante de la academia y la iglesia en la tierra, o se justifica alegando que su señora Marcia ni sabe latín, ni simpatiza con el matrimonio [...] Tanto la ambivalencia del narrador y su narratario como la manipulación de recursos retóricos para manipular al lector cumpliendo o traicionando sus expectativas, dan paso a la creación de un texto plural y contradictorio que anticipa (junto con el Quijote, la picaresca y la novela moderna) las prácticas de la novela moderna. ${ }^{77}$

\footnotetext{
${ }^{74}$ Véase Induráin, p. 144. Cfr. Avalle-Arce, "Lope entre dos mundos", NRFH, XXIV (1975), reproducido en Dintorno de una época dorada, Madrid, Porrúa, 1978, pp. 339-352, esp. p. 350.

${ }^{75}$ Véase complementariamente lo que dice a este respecto Antonio Carreño en el prólogo a su edición de las Novelas (Madrid, Cátedra, 2002, pp. 58-59).

${ }^{76}$ Son palabras de Antonio Carreño, en el prólogo de su edición de las Novelas ya citada, p. 28.

77 Carmen R. Rabell, Lope de Vega. El arte nuevo de hacer 'novellas', Londres, Tamesis Books Ltd., 1992, p. 82. Las intromisiones de Lope en el texto y las digresiones que se introducen han sido los aspectos en los que ha incidido más la crítica de las Novelas; véanse los siguientes trabajos: Juan Bautista Avalle-Arce, "Lope entre dos mundos", art. cit; y, sobre todo, los artículos de Gonzalo Sobejano, "La digresión en la prosa narrativa de Lope de Vega y en su poesía epistolar", Estudios ofrecidos a Emilio Alarcos Llorach, Oviedo, Universidad de Oviedo, 1978, vol. II, pp. 479-494; y Carmen Hernández Valcárcel, "El arte de la digresión y la voz del narrador en las Novelas a Marcia Leonarda", Anales de la Universidad de Murcia, XXXVII, 4 (1980), pp. 263-281.
} 
Si se repasa brevemente algunas de las más conocidas obras del género (Noches de invierno, de Eslava o Cigarrales de Toledo, de Tirso de Molina, por ejemplo) se podrá observar que también se producen este tipo de intromisiones o intervenciones directas del narrador; pero en mucha menor medida que en las Novelas a Marcia Leonarda y, además, no suelen dar lugar a digresiones extensas. Estas suelen venir introducidas por los propios personajes de la narración, no por el autor, que, por otra parte, aunque se siente plenamente dominador del curso de la narración (Cigarrales, pp. 163, 213, 218, 281, 307, $355,429$; Noches, $69,172,266,278,318,326,327),{ }^{78}$ no se lo repite al lector de la manera tan abrumadora de Lope, que lleva de la mano a aquél por los vericuetos de la narración. En efecto, desde un primer momento, Lope se incorpora en el relato guiando la propia lectura de las novelas tanto a Marta de Nevares, como a cualquier otro lector de ellas. He aquí algún ejemplo. En Las fortunas de Diana, Lope introduce un largo romance (pp. 42-44) en el que el personaje Fabio refiere sus quejas de amor:

¡Ay verdades, que en amor siempre fuistes desdichadas! Buen ejemplo son las mías, pues con mentiras se pagan. [...]

Inmediatamente antes nos da la opción de leerlo o, simplemente, de seguir la narración de los hechos: "comenzó a cantar así (y vuestra merced, señora Leonarda, si tiene más deseo de saber las fortunas de Diana que de oír cantar a Fabio, podrá pasar los versos de este romance sin leerlos; o si estuviere más de espacio su entendimiento, saber qué dicen estos pensamientos quejosos a poco menos enamorada causa)" (p. 42).

En otras ocasiones aclara cosas que podrían haber quedado incompletas: "Parécenme que dice vuestra merced que claro estaba eso, y que, si había hija en esa casa, se había de enamorar del disfrazado mozo. Yo no sé que ello haya sido verdad, pero por cumplir con la obligación del cuento, vuestra merced tenga paciencia y sepa que la dicha Silveria tendría hasta diecisiete o dieciocho años, edad que obliga a semejantes pensamientos" (p. 52). Y aclara también

\footnotetext{
${ }^{78}$ Para Cigarrales manejo la edición ya citada (Madrid: Castalia, 1996) y para Noches, la siguiente: Antonio de Eslava, Parte primera del libro intitulado Noches de inuierno [1609], ed. y pról. de Luis M. González Palencia, Madrid, SAETA, 1942.
} 
posibles descuidos de la novela (p. 60), lo que da lugar a una larga digresión de Lope, de la que es plenamente consciente ("Atrévome a vuestra merced con lo que se me viene a la pluma, porque sé que, como no ha estudiado retórica, no sabrá cuánto en ella se reprehenden las digresiones largas", p. 61).

En fin, los ejemplos se podrían multiplicar. Muestran a un escritor, plenamente consciente de su papel de narrador, que maneja las riendas del relato haciéndose presente de manera reiterada según avanzan las páginas de la obra y que, además, sabe dirigir, guiar al lector, a quien, en definitiva, manipula con mucha habilidad. Todo ello no es fácil encontrarlo en la narrativa corta de la época y constituye, pienso, la gran aportación de Lope a este género.

Otra cuestión es que Lope creara escuela. Lo cierto es que sus novelas no se editan nuevamente hasta varios años después de la muerte de su autor: en 1648, 1649 y 1650 en el seno de un tomo bajo el título Novelas amorosas de los mejores ingenios de España. Parece, pues, que no tuvo el éxito de sus narraciones anteriores, aunque, posiblemente, otra cosa hubiera sucedido de haberlas editado Lope de manera independiente: el hecho de publicarse en el seno de otras obras más extensas nos impide calibrar ajustadamente la aceptación entre el público del ensayo lopesco.

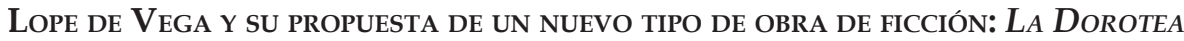
EN EL CONTEXTO DE LA PROSA DE LA ÉPOCA

Ya en el umbral de sus últimos días, Lope sorprende publicando una nueva obra en prosa, muy distinta a todas la anteriores, de título inquietante (La Dorotea. Acción en prosa) y de muy difícil encasillamiento con respecto a los géneros de ficción del momento, hasta tal punto que todavía en la actualidad no se sabe a ciencia cierta dónde situarla.

La Dorotea responde en primer momento a una circunstancia de la época que se debe tener presente: la pragmática que prohibió la publicación de novelas y comedias entre 1625 y $1634 .{ }^{79}$ Lope satisface, pues, sus deseos de comunicación

\footnotetext{
${ }^{79}$ Véanse a este respecto los trabajos de Jaime Moll, “Diez años sin licencias para imprimir comedias y novelas en los reinos de Castilla: 1625-1634", BRAE, LIV (1974), pp. 97-103; y “Por qué escribió Lope La Dorotea?", 1616. Anuario de la Sociedad de Literatura General y Comparada, II (1979), pp. 7-11; y Anne Cayuela, “La prosa de ficción entre 1625 y 1634. Balance de diez años sin licencias para imprimir novelas en los reinos de Castilla", MCV, XXVIII (1993), pp. 51-76; “Las mujeres de Lope: un seductor en sus dedicatorias", Edad de Oro, XIV (1995), pp. 78-83; Le paratexte au Siècle d'Or, Geneve, Droz, 1996.
} 
con sus lectores a través de una narración que no responde a los géneros en boga del momento: no es pastoril, ni bizantina, ni novela a la italiana. Es algo completamente distinto, que se ha podido emparentar con la comedia latina (Terencio, Plauto), pero que es algo más. Puede ser, efectivamente, como señala Márquez Villanueva, una "fina adaptación al Madrid de los Austrias del alto mundo meretricio de la comedia latina", que entronca, pues, de manera directa con la literatura celestinesca. ${ }^{80}$ En efecto, Lope vuelve los ojos a una obra por la que había tenido siempre una especial inclinación: La Celestina. De ella conserva, según recuerda José Manuel Blecua, la estructura formal, la acción en prosa dialogada y la moralidad que se desprende del prólogo; pero, por lo pronto, entre Gerarda y Celestina media todo un mundo, son dos personajes, en el fondo, muy distintos. ${ }^{81}$ Y lo mismo sucede con el resto de personajes. La Dorotea, pues, acaba no pareciéndose siquiera a su modelo más inmediato ${ }^{82} \mathrm{y}$, por otra parte, ha legado a la posteridad un cierto grado de hermetismo dada la propia calificación otorgada por su autor: Acción en prosa. De hecho, Lope no aclara mucho la situación cuando en el prólogo (Al teatro de don Francisco López de Aguilar) no duda en señalar que La Dorotea es poesía, "aunque escrita en prosa".

Con todo, Lope quiere llevar a cabo una obra en prosa que contenga todos los elementos que la literatura de entretenimiento de la época exigía: imitación de la verdad (= verosimilitud), variedad, erudición, mezcla de verso y $\operatorname{prosa}^{83}$ y que responda a la formulación horaciana de utile dulci: ${ }^{84}$

\footnotetext{
${ }^{80}$ Francisco Márquez Villanueva, “Literatura, lengua y moral en La Dorotea”, Lope, vida y valores, op. cit., pp. 143-267. Véanse también los trabajos de Christian Andrés, "La problématique du genre et un genre problématique: La Dorotea", Les Langues Néo-Latines, 319 (2001), pp. 81-104; Jean-Michel Laspéras, "La Dorotea de Lope de Vega, 'ce genre d'écriture'", Hommage à Alain Milhou, Cahiers du CRIAR (Univ. de Rouen), 21 (2003), pp. 243-261; y Nadine Ly, "La Dorotea de Lope: Acción en prosa. Réflexions sur un sous-titre", Bulletin Hispanique, 2 (2002), pp. 767-810. Asimismo, el volumen coordinado por esta última autora, Lectures d'une oeuvre. La Dorotea de Lope de Vega, Paris, Éditions du temps, 2001, incorpora un capítulo sobre esta cuestión de Natalie Dartai-Maranzana, "Le portraitpuzzle de la divine Dorotea ou l'ambigüité du personaje-titre", pp. 31-53.

${ }^{81}$ Véase Lope de Vega, La Dorotea, ed. José Manuel Blecua (Madrid, Cátedra, 1996), pp. 43-44.

${ }^{82}$ Esto es, la propia Celestina; cfr. lo que dice el propio Lope al inicio de la obra (ed. Morby, p. 54) y Márquez Villanueva, p. 149. Véase también Harry Vélez - Quiñones, La celestinesca, la comedia y "La Dorotea": huellas de un intertexto, Salamanca, Ediciones de la Universidad de Salamanca, 1994.

${ }^{83}$ Además de lo que dice el párrafo incorporado al cuerpo del texto téngase presente este otro: "La causa de que los poetas escriuiendo prosa mezclen en ella versos medidos, es el vso de escriuirlos; de que se enfadan los dos filósofos, y con mucha razón. Pero el que fuere poeta natural no podrá remediar este defeto, si no es con mucho cuidado" (IV, 3, p. 350).

${ }^{84}$ Recuérdese en este sentido la cita ciceroniana con la que se cierra La Dorotea: "lectionem sine vlla delectatione negligo" (ed. Morby, p. 459).
} 
[...] si bien ha puesto algunos [versos] que ellas refieren La Dorotea de Lope lo es, aunque escrita en prosa, porque siendo tan cierta imitación de la verdad, le pareció que no lo sería hablando las personas en verso como las demás que ha escrito; [...] y porque no le falte a La Dorotea la variedad, con el deseo de que salga hermosa [...] Si algún defeto huuiere en el arte -por ofrecerse precisamente la distancia del tiempo de vna ausencia- sea la disculpa la verdad; que más quiso el poeta seguirla que estrecharse a las impertinentes leyes de la fábula. Porque el assunto fue historia, y aun pienso que la causa de auerse con tanta propriedad escrito; yo lo he sido de que salga a la luz, aficionado al argumento y al estilo. Al que le pareciere que me engaño, tome la pluma; y lo que auía de gastar en reprehender, ocupe en enseñar que sabe hazer otra imitación más perfeta, otra verdad afeitada de más donaires y colores retóricos, la erudición más ajustada a su lugar, lo festiuo más plausible y lo sentencioso más graue; con tantas partes de filosofía natural y moral que admira cómo aya podido tratarlas con tanta claridad en tal sujeto. (Ed. Morby, pp. 51-53).

Y además que tuviera un poso clásico ${ }^{85}$ una tradición conocida y noble, a la que, por otra parte, va a intentar superar: "[...] y porque no le falte a $L a$ Dorotea la variedad, con el deseo de que salga hermosa, aunque esto pocas veces se vea en las griegas, latinas y toscanas" (ed. Morby, p. 51). Se trata por tanto de un nuevo ensayo de Lope que, con una base en una tradición clásica y ajustándose a las exigencias de la narrativa de entretenimiento, quiere superar todo lo anterior. En este sentido, La Dorotea puede considerarse como la gran obra de Lope, en la que realmente quiso destacar, dejar su propio y novedoso legado, en definitiva su aportación más personal a la ficción narrativa áurea.

Pero, ¿por qué quiere hacer esto Lope de Vega con setenta años a las espaldas? De nuevo por su deseo de estar en candelero, de ser considerado

\footnotetext{
${ }^{85}$ Son evidentes las pretensiones lopescas de crear una obra clásica: recuérdense simplemente los versos finales de cada acto que siguen moldes latinos: sáficos adónicos, dímetros iámbicos, dícolos distrophos, "Hendecasílabos falecios" y "alcmanios euripideos", respectivamente. Morby (ed. cit., p. 128) afirma sobre esta cuestión: "Lope quiere también realzar el aspecto clásico de su Dorotea, ya marcada por la división en cinco actos. Pero no sin cierta intención irónica [...] Si con términos pomposos y versos de supuesta configuración clásica subraya lo ordinario de los actores y lo huero de sus actitudes, al mismo tiempo destaca lo que verdaderamente tienen de auténtica tragedia". Véase a este respecto mi trabajo "La Dorotea como tragedia", Isabel Lozano Renieblas y Juan Carlos Mercado, eds., Silva. Studia philologica in honorem Isaías Lerner, Madrid, Castalia, 2001, pp. 479-48. Cfr. Jean Pierre Étienvre, "Castigo y venganza en La Dorotea", Anuario Lope de Vega, 8 (2002), pp. 19-34. Otros argumentos que ayudan a revelar el poso clásico de La Dorotea se hallarán en el artículo de Lía Schwartz, "La construcción de La Dorotea: entre Séneca y Ovidio", Anuario Lope de Vega, 8 (2002), pp. 177-196.
} 
escritor culto $\mathrm{y}$, finalmente, como ha puesto de relieve la crítica, por su desesperado intento de buscar, al final de su vida, dignidad en tres planos: moral (tras sus abundantes escándalos amorosos), económico (atrás quedan sus intentos de ser nombrado cronista real) y, sobre todo, literario. Se trata, en fin, de una obra inserta de lleno en el ciclo que Juan Manuel Rozas bautizó como De senectute. ${ }^{86}$

En este sentido, La Dorotea "quiere ser, entre otras cosas, la gran réplica frente a la competencia y los ataques de los nuevos escritores, y el gran mérito final que Lope presenta como credencial con vistas a conseguir alguna recompensa de quien veía como poderosos olvidadizos e injustos" ${ }^{87}$ Lope perseguía ser considerado un escritor docto y defender su primacía frente a los pájaros nuevos o noveles, jóvenes escritores que comenzaban a ganarle la partida: dramaturgos como Jerónimo de Villaizán, Mira de Amescua, Coello, Diamante, Cubillo de Aragón y, muy especialmente, Calderón de la Barca. Uno de esos jóvenes que competían con él y que se convirtió en gran enemigo para Lope fue el joven José Pellicer de Salas (1602-1679) erudito comentarista de Góngora. ${ }^{88}$

Y para llevar a cabo tales propósitos Lope acude no sólo a un género clásico que va a renovar, sino también a su mejor fuente de inspiración: su propia vida, en la que se basa la trama central de La Dorotea, construida sobre ese episodio que tanto parece haberle marcado y que reitera de manera intermitente en varias obras: sus amores con Elena Osorio, ${ }^{89}$ con la intención, por una parte, de historiarlos, novelarlos, pero, por otra, en mi opinión, de legar a la posteridad una imagen determinada de sí mismo. No se trata ya de

\footnotetext{
${ }^{86}$ Juan Manuel Rozas, “El 'ciclo de senectute': Lope y Felipe IV", Estudios sobre Lope de Vega, Madrid, Cátedra, 1990, pp. 73-131. Véanse también, los trabajos de Márquez Villanueva (art. cit.) y, sobre todo de Francisco J. Ávila, "La Dorotea: arte y estrategia de senectud, entre la serenidad y la desesperación", Edad de Oro, XIV (1995), pp. 9-27. Debe leerse también el certero trabajo de Maria Grazia Profeti, “El último Lope", Felipe B. Pedraza Jiménez y Rafael González Cañal, eds., La década de oro en la comedia española: 1630-1640. Actas de las XIX Jornadas de teatro clásico, Almagro, julio de 1996, Almagro, Ediciones Universidad de Castilla La Mancha, 1997, pp. 11-39; y los más recientes de Belén Atienza, “A una hermosa con ojo de cristal: La Dorotea y las Rimas de Burguillos en el ciclo De senectute", Anuario Lope de Vega, 8 (2002), pp. 9-18; y Begoña López Bueno, “Las tribulaciones literarias del Lope anciano: una lectura de La Dorotea, I, II y III", Anuario Lope de Vega, 11 (2005), pp. 145-164.

${ }^{87}$ Ávila, art. cit., p. 12.

${ }^{88}$ Cfr. ibidem, p. 10.

${ }^{89}$ Véase Márquez Villanueva (p. 146, nota 10) y Ávila (p. 18, nota 31) con bibliografía complementaria.
} 
reflejar sólo la vida vivida o soñada, sino acaso la que se quiere perpetuar, no sin un importante desengaño vital: "Como obra literaria, La Dorotea es la mejor en prosa del autor. Está escrita con la vivacidad y nervio de lo vivido. Con estilo suave nos va llevando de la mano a través del proceso sensual hasta llegar a saborear el amargor del desengaño. Está contenida en aquellas páginas toda una evolución psicológica que empieza en el fuego de una pasión aturdida y acaba en un desmoronamiento sentimental y melancólico" ${ }^{90}$

La Dorotea, en este sentido, se muestra como la obra de Lope en la que más y mejor se revelan sus grandes obsesiones:

1) Su amor de juventud, acaso el más valioso de su vida. Bajo los nombres de Don Fernando, Dorotea, Don Bela se esconden los nombres del propio Lope, Elena Osorio y Francisco Perrenot de Granvela. Además parece lo esencial en su vida, lo que realmente mereció la pena, aquello que sí debe relatarse. Todo lo demás, como dice la Fama en la última escena de la obra, "fueron trabajos de Don Fernando". ${ }^{91}$

2) Su relación con Góngora, enemistad y admiración unidas (siempre aparece con el tratamiento de don $)^{92} \mathrm{y}$, junto a ella, el ataque despiadado a los gongoristas. ${ }^{93}$

3) Sus alardes eruditos, siempre presentes. ${ }^{94}$

4) Su presunción: Don Fernando (Lope, en definitiva), es caballero y, en consecuencia, se le da el tratamiento de don. Bien conocidos son los aires de grandeza de nuestro autor y sus intentos de autoennoblecimiento, que motivaron

\footnotetext{
${ }^{90}$ Son palabras de José María Viqueira, El lusitanismo de Lope de Vega y su comedia "El Brasil restituido". Estudio bio-bibliográfico, notas y comentarios, Coimbra, Coimbra Editora, 1950, p. 140.

91 "La Fama. -Senado, ésta es La Dorotea, este fin tuuieron don Bela, Marfisa y Gerarda. Lo que resta fueron trabajos de don Fernando. No quiso el poeta fallar a la verdad, porque lo fue la historia". Escena última, ed. Morby, p. 456. Cfr. lo que dice el propio Morby al respecto (p. 440): "Pero reconociendo lo peligroso de querer solucionar el enigma de un autor muerto a tan gran distancia de tiempo y espacio, me siento tentado de ver otro motivo todavía, tal vez medio inconsciente, y de encontrar la clave de la clave y cifra de la cifra en una frase final de la obra puesta en boca de la Fama: [es la cita anterior] $i$ "Lo que resta"!: toda una vida, pero vida condensada en unas frases y resumida en la mitad de otra. Lo esencial, lo que ha valido la pena de contarse por extenso, es La Dorotea. Lope durante un momento intuye que La Dorotea es su vivir, que lo demás, en cierto sentido, fue sobrevivirse".

${ }_{92}^{2}$ III, 7 (Ed. Morby, p. 267), IV, 2 (p. 322).

${ }^{93}$ Ed. Morby, pp. 317-319. Cfr. Márquez Villanueva, pp. 206-210.

${ }^{94}$ Véanse los trabajos de Félix Monge, Félix, "La Dorotea de Lope de Vega", Vox Romanica, XVI (1957), pp. pp. 60-145; y “'Literatura' y erudición en La Dorotea”, Homenaje a José Manuel Blecua, Madrid, Gredos, 1983, pp. 449-463.
} 
la crítica furibunda de Góngora. Que en La Dorotea se trate a sí mismo como caballero (Don Fernando) puede interpretarse como otro intento en ese sentido, pero, por otro lado, consecuentemente con lo ya expuesto, como la imagen que de sí mismo como caballero quería dejar a la posteridad: un Lope caballero, con un tratamiento superior al que le correspondía.

5) La lucha con los preceptos literarios, constante en Lope. ${ }^{95}$

6) Presencia de la astrología, aquí no sólo ya como un tema muy querido para Lope sino con una importante función estructural, como ha estudiado certeramente Márquez Villanueva: ${ }^{96}$ Lope confía el enjuiciamiento definitivo de sus personajes a unos horóscopos que le permiten "ver el desenlace en toda su profundidad y concilian la existencia de no uno sino dos finales, a respectivos corto y largo plazo" ${ }^{97}$

Lope de Vega no salió a disgusto de este ensayo. Su obra, recibida más bien con indiferencia, contaba sin embargo con el mayor beneplácito por parte de su autor:

Póstuma de mis musas Dorotea, y por dicha de mí la más querida, última de mi vida pública luz desea. ${ }^{98}$

Ya era tarde para la gloria. El escritor no pudo disfrutar apenas de esta su gran obra. Pero legó a la posteridad acaso su mejor creación, esa síntesis de vida y literatura, de tradición e innovación que sólo su genio podía crear. Los

\footnotetext{
${ }^{95}$ Véanse pp. 52 (sobre "las leyes de la fábula"), 186 y 448 (sobre tópicos de la novela pastoril), 236 (sobre la literatura clásica), 328-329 (sobre las comedias), etc.

${ }^{96}$ Márquez Villanueva, op. cit., pp. 187-189.

${ }^{97}$ Ibidem, p. 188. "Por encima de sus santos propósitos, Dorotea naturalmente no será monja, pues volverá a casarse, enviudará y de nuevo va a volcar sus seducciones sobre Fernando, solicitándolo ahora por marido. No le espera ninguna clase de futuro heroico bajo el signo de Marte, pues lo mismo que Dorotea "tenéis la luna en la duodécima parte de los pezes, en dignidad de Venus". Por el contrario, habrá de sufrir en sus amores infinitos trabajos, sin ahorrarse (igual que Lope) ni aun el de ser blanco de aborrecibles hechicerías. La desdichada Marfisa volverá, sin su codiciado Fernando a la rueda de sus matrimonios (similar y paralela a la de los amantes en Dorotea) y acabará asesinada, lejos de la patria, por un marido celoso. Si "Fernando" termina en hábitos sacerdotales, ya sabemos nosotros lo que después le esperaba y, aunque Lope no pudiera decirlo en letra de molde, era en la época de dominio bien público". Ibidem, pp. 188-189.

${ }^{98}$ Vv. 403-406 de la Egloga a Claudio (1632). Ed. García Posada, p. 258.
} 
clarines de la fama acabaron sonando - es, con diferencia, su obra reeditada en más ocasiones - , pero mucho tiempo después. Lope no pudo oírlos.

Tradición e innovación, autobiografía y transfiguración literaria constituyen las bases en que se asienta el conjunto de estos textos con los que Lope de Vega, acaso el dramaturgo español por excelencia, quiso pasar a la posteridad como un escritor culto de obras en prosa. 